\title{
Effects of milk replacer feeding rate and frequency of preweaning dairy calves in the southeastern United States: Performance, abomasal emptying, and nutrient digestibility
}

\author{
Ruth M. Orellana Rivas, ${ }^{1}$ Thalyane Rodrigues, ${ }^{1}$ Jordana da Silveira E. Sousa, ${ }^{1}$ Victor H. L. R. Melo, ${ }^{1}$ \\ Jing Gao, ${ }^{1}$ Diego Ferreira de Araújo, ${ }^{1}$ Juliana Goncalves de Souza, ${ }^{1}$ Thiago N. Marins, ${ }^{1}$ Pedro Melendez, ${ }^{2,3}$ \\ John K. Bernard, ${ }^{1}$ and Sha Tao ${ }^{1 *}$ \\ ${ }^{1}$ Department of Animal and Dairy Science, University of Georgia, Tifton 31793 \\ ${ }^{2}$ Department of Population Health, College of Veterinary Medicine, University of Georgia, Tifton 31793 \\ ${ }^{3}$ Tifton Veterinary Diagnostic and Investigational Laboratory, College of Veterinary Medicine, University of Georgia, Tifton 31793
}

\section{ABSTRACT}

To evaluate the effects of milk replacer (MR) feeding rate $(\mathrm{FR})$ and frequency $(\mathrm{FF})$ on performance, abomasal emptying, and nutrient digestibility in the southeastern United States, Holstein calves $(\mathrm{n}=48 /$ season $)$ were enrolled at $8 \mathrm{~d}$ of age (DOA) during summer [June to August, body weight $(\mathrm{BW} ;$ mean $\pm \mathrm{SD})=40.71 \pm$ $4.35 \mathrm{~kg}]$ and winter (November to January, BW $=42.03$ $\pm 3.83 \mathrm{~kg})$. Within season, calves were randomly assigned to 1 of 4 treatments in a $2 \times 2$ factorial arrangement including $2 \mathrm{FR}[0.65$ (low) or $0.76 \mathrm{~kg}$ of solid per day (high) of a $26 \%$ crude protein and $17 \%$ fat MR], and $2 \mathrm{FF}[2 \times(0700$ and $1600 \mathrm{~h})$ or $3 \times(0700,1600$, and $2200 \mathrm{~h}$ ) daily]. Calves were housed in polyethylene hutches and managed similarly throughout the trial. Milk replacer ( $12.5 \%$ solids) was fed to calves based on their respective treatments until $42 \mathrm{DOA}$, when MR allowance was reduced by $50 \%$ and offered once a day $(0700 \mathrm{~h})$ for the following $7 \mathrm{~d}$ until weaning. Calves remained on trial until 63 DOA. Calf starter and water were offered ad libitum. Ambient temperature and relative humidity inside and outside hutches were measured hourly. Starter and MR intakes were recorded daily. Respiration rate and rectal temperature were recorded 3 times a week. Structural growth and BW were measured weekly. Acetaminophen $(50 \mathrm{mg} / \mathrm{kg}$ of BW) mixed with MR was fed to a subset of calves (0700 h, $\mathrm{n}=10$ / treatment per season) on 20 DOA. Plasma was collected at 15, 30, 60, 90, 120, 150, 180, 210, 240, 270, 300, $330,360,420$, and 480 min after feeding, to analyze acetaminophen. The acetaminophen concentration-time curve was modeled to the first derivative of Siegel's

Received February 11, 2021.

Accepted September 11, 2021.

*Corresponding author: stao@uga.edu modified power exponential equation, and the time for plasma acetaminophen to reach maximum (Tmax) was calculated to evaluate abomasal emptying rate. During the pre- (14.9-17.9 DOA) and postweaning (51.0-54.0 DOA) periods, a subset $(\mathrm{n}=8 /$ treatment per season $)$ of calves was used to determine the apparent digestibility of nutrients, using chromic oxide as the external marker. Feeding $3 \times$ reduced preweaning respiration rate during summer and reduced rectal temperature during winter. Increasing FR improved $\mathrm{BW}$ gain and structural growth. Feeding more times per day tended to improve growth during winter but not summer. We found no effect of treatment on nutrient digestibility. Increasing FR had no effect on Tmax during winter but tended to delay Tmax of plasma acetaminophen during summer. Regardless of season, increasing FF lowered Tmax of plasma acetaminophen. In conclusion, increasing FF accelerated abomasal emptying and might reduce heat load of preweaning dairy calves but improved growth only during winter. Increased MR allowance improved growth in both seasons but delayed abomasal emptying only under heat stress conditions. Key words: milk replacer, season, calf, abomasal emptying

\section{INTRODUCTION}

Calves raised during the summer have reduced growth, increased disease incidence, and higher mortality rates relative to those raised in temperate environments or thermoneutral conditions (Stull et al., 2008; Broucek et al., 2009). The reduced ADG observed in the summer can be partially attributed to heat stress. On many dairy operations, calves are often fed a fixed amount of milk or milk replacer (MR) twice daily and starter grain ad libitum, and weaned around 7 to 8 wk of age (USDA, 2016). When exposed to heat stress, starter intake is reduced (Chavez, 2011), resulting in 
lower total energy and nutrient consumption. Additionally, animals under an adverse environment experience dramatic physiological and behavioral changes to cope with distress. For example, calves in an environment with elevated ambient temperature $\left(\geq 20^{\circ} \mathrm{C}\right)$ increase sweating and panting to dissipate heat and maintain core body temperature (Gebremedhin et al., 1981). These physiological responses, although beneficial for survival, shift available energy from growth to maintenance. Coupled with the lower starter consumption, calves raised during summer have limited energy available for growth (Chavez, 2011).

Therefore, increasing energy intake by feeding more milk or MR should support greater growth during summer. We previously reported that feeding $0.66 \mathrm{~kg}$ of DM per day of an MR containing $26 \% \mathrm{CP}, 17 \%$ fat, and $47 \%$ lactose (26:17, as-fed basis) twice daily improved BW gain of preweaned calves compared with those fed $0.55 \mathrm{~kg}$ of DM per day of an MR containing $20 \% \mathrm{CP}$, $20 \%$ fat, and $51 \%$ lactose (20:20, as-fed basis) in the summer (Orellana Rivas et al., 2020). However, increasing MR (26:17) allowance to $0.77 \mathrm{~kg}$ of DM per day had no additional improvement on growth rate, but further increasing $\mathrm{MR}$ allowance to $0.87 \mathrm{~kg}$ of $\mathrm{DM}$ per day was associated with increased incidence of abomasal bloating and calf death (Orellana Rivas et al., 2020). Interestingly, experiments carried out in temperate environments reported that feeding larger amounts of MR twice daily improves growth without any reported digestive disorders (Chapman et al., 2016; Hill et al., 2016b). In temperate environments, increased milk or MR feeding rate (FR) slows abomasal emptying (MacPherson et al., 2016). This is related to increased heat production from the oxidation of amino acids and carbohydrates on the BW basis (van den Borne et al., 2006, 2007; Burgstaller et al., 2017). However, delayed abomasal emptying is considered a mechanism for regulating the large influx of nutrients into the small intestine and has an insignificant effect on growth (van den Borne et al., 2006). Heat stress also slows the passage rate of digesta through the gastrointestinal tract in dairy cattle (McDowell et al., 1969). This may further delay abomasal emptying when feeding large amounts of MR during summer, leading to exaggerated energy loss and disturbed digestion. These may explain the lack of growth improvement and increased digestive disorders of calves fed higher amounts of MR in our previous study (Orellana Rivas et al., 2020).

As discussed by van den Borne et al. (2006), increasing milk or MR feeding frequency (FF) reduces meal size and increases gastric emptying of digesta. This theoretically accelerates abomasal emptying and reduces the energy expenditure caused by gastric hypertrophy and energy loss during abomasal fermentation of carbohydrates, thereby improving the efficiency of energy utilization. In veal calves, increasing FF from 2 to 4 times a day $(2 \times$ and $4 \times$, respectively) improved retention of energy and protein (van den Borne et al., 2006, 2007). However, similar research has never been conducted in tropical or subtropical environments. Such research should provide feasible recommendations that dairy producers may use to improve calf wellbeing and growth during heat stress conditions. Therefore, our hypothesis was that calves fed increased quantities of MR during the summer have delayed abomasal emptying, and that increasing FF will accelerate abomasal emptying and improve nutrient utilization and growth. The objective of this study was to evaluate the effects of FR and FF on performance, abomasal emptying, and nutrient digestibility during summer and winter in the southeastern United States.

\section{MATERIALS AND METHODS}

\section{Animal Handling and Experimental Design}

The experiment was conducted on the Dairy Research Center of the University of Georgia-Tifton Campus. Experimental procedures were approved by the University of Georgia Institutional Animal Care and Use Committee (AUP no. A2018 02-011-Y1-A0) before the beginning of the study. The experimental design and procedures were performed in 2 seasons: summer, from May to October 2018, and winter, from November 2018 to April 2019. A total of 96 ( $\mathrm{n}=48$ per season) newborn calves were enrolled in the experiment. Before the experiment, to the best of our knowledge, only one study had compared feeding an accelerated MR program (2 vs. 3 times a day) on performance of dairy calves, and the results were reported in abstract form without standard errors (Sockett et al., 2011). Therefore, the starter intake data (1.00 vs. $1.30 \mathrm{~kg} / \mathrm{wk}, \mathrm{SD}=$ $0.35 \mathrm{~kg} /$ wk, $P<0.05$; Kmicikewycz et al., 2013) at the week after weaning of calves fed a 20:20 MR $2 \times$ and $4 \times$ daily were used to calculate power. The sample size of 23 calves per feeding frequency was calculated using a level of significance of 0.05 and $80 \%$ power. Researchers were not blinded to the treatment allocation.

Within $6 \mathrm{~h}$ after birth, all calves were separated from their dams, navel-dipped in $7 \%$ tinctured of iodine (Vetericyn Super 7+, Innovacyn Inc.), and fed a colostrum replacer containing at least $200 \mathrm{~g}$ of $\operatorname{IgG}$ (Bovine IgG colostrum replacer, Land O'Lakes Inc.). At $7 \mathrm{~d}$ of age (DOA), calves were dehorned using a caustic paste (Dehorning Paste, H. W. Naylor Company Inc.). The day of birth was considered as 1 DOA. Starting at $2 \mathrm{DOA}$, calves were fed $0.65 \mathrm{~kg}$ of $\mathrm{DM}$ per day of a 26:17 MR (Provimi North America Inc.) twice daily 
(0700 and 1600 h) until 7 DOA. At 8 DOA, calves were weighed and randomly assigned to 1 of 4 treatments in a $2 \times 2$ factorial arrangement. Treatments included 2 FR $[0.65$ (low) or 0.76 (high) $\mathrm{kg}$ of DM per day of the $26: 17 \mathrm{MR}]$ and $2 \mathrm{FF}[2 \times(0700$ and $1600 \mathrm{~h})$ or $3 \times$ daily $(0700,1600$, and $2200 \mathrm{~h})]$. These resulted in 4 treatment combinations ( $\mathrm{n}=12 /$ treatment per season): low $2 \times$ (summer: 5 heifers, 7 bulls; winter: 6 heifers, 6 bulls), low3 $\times$ (summer: 6 heifers, 6 bulls; winter: 5 heifers, 7 bulls), high2 $\times$ (summer: 6 heifers, 6 bulls; winter: 5 heifers, 7 bulls), and high3 $\times$ (summer: 6 heifers, 6 bulls; winter: 5 heifers, 7 bulls). During winter, 2 calves died due to scour $(1$ high $2 \times$ bull at $11 \mathrm{DOA}$, 1 high $3 \times$ heifer at 15 DOA), and 1 calf died because of respiratory disease $(1$ low $2 \times$ bull at $8 \mathrm{DOA})$. Their data were not included in the analysis, and 3 additional calves were enrolled to maintain 12 calves/treatment per season. The MR FR (0.65 vs. $0.76 \mathrm{~kg}$ of $\mathrm{DM} / \mathrm{d})$ were selected based on our previous study (Orellana Rivas et al., 2020). Compared with those fed $0.55 \mathrm{~kg}$ of DM per day of a 20:20 MR, feeding $0.66 \mathrm{~kg}$ of DM per day of a 26:17 MR improved ADG of preweaning calves raised in summer. However, further increasing FR from 0.66 to $0.77 \mathrm{~kg}$ of DM per day of the 26:17 MR showed no additional improvement in ADG, and feeding an aggressive amount of MR $(0.87 \mathrm{~kg}$ of DM/d) was associated with increased incidence of abomasal bloating (Orellana Rivas et al., 2020). The BW was not different $(P>0.40)$ among treatments at the onset of the treatment period during both summer and winter, and averaged (mean \pm SD) $40.71 \pm 4.35 \mathrm{~kg}$ and $42.03 \pm$ $3.83 \mathrm{~kg}$, respectively. All calves were managed similarly and housed in individual polyethylene hutches bedded with sand in an open area without shade. Bedding was cleaned twice daily and replaced once weekly.

\section{Feeding, Intake, and Growth Measurements}

Milk replacer was medicated with lasalocid $(96 \mathrm{mg} /$ $\mathrm{kg}$ ) and was composed of dried whey, dried milk protein, dried whey products, and vegetable and animal fats. Textured calf starter (18\% CP, Godfrey's Warehouse Inc.) and water were offered ad libitum from 2 DOA and throughout the experiment. Water buckets were cleaned twice daily and refilled as needed during the day. Milk replacer was reconstituted with warm water $\left(43-45^{\circ} \mathrm{C}\right)$ to $12.5 \%$ solids and divided into equal amounts per feeding according to FF. At 43 DOA, FR was reduced by half and offered once daily $(0700 \mathrm{~h})$ for all calves until 49 DOA. Calves remained in the hutches until 56 DOA and were then transferred to individual stalls in a ventilated barn until the end of the experiment at 63 DOA. Starter intake was measured daily, and the amount of MR refused was recorded to calculate MR intake. Representative samples of starter and MR were collected weekly and pooled monthly for chemical analysis at Cumberland Valley Analytical Services (Waynesboro, PA; Table 1). Growth was assessed by measuring BW, body length, withers height, and hip height on a weekly basis (1000 h).

\section{Environmental Conditions, Rectal Temperature, Respiration Rate, Health Scores, and Morbidity}

During the experiment, environmental temperature and relative humidity were measured every 15 min us-

Table 1. Chemical analysis (mean $\pm \mathrm{SD}$ ) of milk replacer (MR) and calf starter

\begin{tabular}{|c|c|c|c|c|}
\hline Item, DM basis & $\begin{array}{c}\text { MR } \\
(\mathrm{n}=6) \\
\text { Summer }\end{array}$ & $\begin{array}{c}\text { MR } \\
(\mathrm{n}=5) \\
\text { Winter }\end{array}$ & $\begin{array}{c}\text { Calf starter } \\
(\mathrm{n}=6) \\
\text { Summer }\end{array}$ & $\begin{array}{c}\text { Calf starter } \\
(\mathrm{n}=6) \\
\text { Winter }\end{array}$ \\
\hline $\mathrm{CP}, \%$ & $27.98 \pm 1.51$ & $26.22 \pm 0.67$ & $17.77 \pm 0.66$ & $18.43 \pm 1.33$ \\
\hline Fat, $\%$ & $19.01 \pm 1.03$ & $18.37 \pm 1.32$ & $4.13 \pm 0.58$ & $4.17 \pm 1.38$ \\
\hline Lactose, ${ }^{1} \%$ & $46.18 \pm 1.78$ & $48.91 \pm 0.68$ & - & - 120 \\
\hline $\mathrm{ADF}, \%$ & - & - & $10.98 \pm 0.67$ & $10.77 \pm 0.21$ \\
\hline $\mathrm{aNDF}_{\mathrm{OM}},{ }^{2} \%$ & - & - & $19.67 \pm 1.26$ & $18.09 \pm 1.13$ \\
\hline NFC, $\%$ & - & - & $52.55 \pm 1.18$ & $51.00 \pm 1.86$ \\
\hline Ash, \% & $6.82 \pm 0.48$ & $6.42 \pm 0.21$ & $6.56 \pm 0.29$ & $6.81 \pm 0.87$ \\
\hline $\mathrm{ME},{ }^{1} \mathrm{Mcal} / \mathrm{kg}$ & $4.81 \pm 0.06$ & $4.76 \pm 0.06$ & $3.04 \pm 0.03$ & $3.02 \pm 0.06$ \\
\hline Calcium, \% & $0.82 \pm 0.10$ & $0.78 \pm 0.04$ & $0.88 \pm 0.11$ & $0.91 \pm 0.24$ \\
\hline Phosphorus, \% & $0.65 \pm 0.05$ & $0.61 \pm 0.03$ & $0.50 \pm 0.03$ & $0.51 \pm 0.03$ \\
\hline Magnesium, \% & $0.09 \pm 0.01$ & $0.09 \pm 0.00$ & $0.27 \pm 0.01$ & $0.26 \pm 0.03$ \\
\hline Potassium, \% & $1.41 \pm 0.07$ & $1.48 \pm 0.09$ & $1.52 \pm 0.05$ & $1.51 \pm 0.11$ \\
\hline Sodium, \% & $0.65 \pm 0.05$ & $0.58 \pm 0.02$ & $0.25 \pm 0.02$ & $0.39 \pm 0.19$ \\
\hline Iron, $\mathrm{mg} / \mathrm{kg}$ & $85.67 \pm 44.84$ & $54.00 \pm 19.33$ & $263.33 \pm 41.93$ & $255.50 \pm 35.99$ \\
\hline Manganese, mg/kg & $38.67 \pm 25.46$ & $21.2 \pm 10.06$ & $112.17 \pm 26.69$ & $89.17 \pm 20.66$ \\
\hline Zinc, mg/kg & $16.83 \pm 2.93$ & $16.00 \pm 1.41$ & $162.17 \pm 21.83$ & $111.50 \pm 22.35$ \\
\hline Copper, mg/kg & $6.67 \pm 1.63$ & $8.50 \pm 7.29$ & $22.33 \pm 6.62$ & $20.67 \pm 5.16$ \\
\hline
\end{tabular}

${ }^{1}$ Lactose and ME calculated according to NRC (2001).

${ }^{2} \mathrm{NDF}$ determined using amylase and corrected for ash. 
ing Hobo Series Temp probes (Onset Computer Corp.). To evaluate the environment inside the hutch, a Hobo probe was hung in the center of an empty hutch, approximately $0.75 \mathrm{~m}$ above the ground. The ambient environment outside the hutch was assessed using another Hobo probe installed on a wooden fence post adjacent to the hutches. Rectal temperature was measured using a thermometer (20-s digital thermometer, 144-920-000, ReliOn, Mabis Healthcare Inc.) and respiration rate assessed by counting flank movements for 1 min for all calves on Monday, Wednesday, and Friday each week $(1430 \mathrm{~h})$. Health scores were assessed twice daily (0700 and $1600 \mathrm{~h}$ ) using the calf health scoring chart developed by the School of Veterinary Medicine, University of Wisconsin-Madison (2011). Health scores included fecal scores defined as 0 (normal), 1 (semi-formed, pasty), 2 (loose, but stays on top of bedding), and 3 (watery, sifts through bedding); cough scores defined as 0 (none), 1 (single cough), 2 (induced or spontaneous occasional cough), 3 (repeated spontaneous coughs); nasal discharge scores defined as 0 (normal discharge), 1 (minimal unilateral cloudy discharge), 2 (bilateral mucus discharge), 3 (copious mucopurulent discharge); ear scores defined as 0 (normal), 1 (ear flick), 2 (unilateral drop), 3 (head tilt); eye score defined as 0 (normal), 1 (minimal ocular discharge), 2 (moderate bilateral discharge), 3 (heavy ocular discharge). Rectal temperature was monitored when total respiratory scores were equal to or higher than 3 or fecal scores were equal to or higher than 2; feverish temperatures were determined when calves had rectal temperatures $\geq 39.5^{\circ} \mathrm{C}$.

Disease records (scours, respiratory diseases, and navel, ear, or cutaneous infections) were collected every day from all calves after a consistent calf health monitoring program. Disease incidence was calculated by obtaining the number of new cases of a specified disease divided by the total amount of calves under risk within each treatment group. Scours was diagnosed by the appearance of loose feces (fecal scores $\geq 2$ ), reduced or no MR intake, and dehydration. Dehydration level was assessed by suckling reflex, demeanor, gum appearance, skin tenting, and sunken eyes. When scours were diagnosed, the afternoon MR feeding was replaced by electrolytes (Re-Sorb, Zoetis Services LLC) for 3 to 5 d until recovery. Calves with fever were treated with 1 intravenous dose of flunixin meglumine (Banamine, Merck Animal Health Intervet Inc.) and 3 intramuscular doses of ceftiofur sodium $24 \mathrm{~h}$ apart (Naxcel, Zoetis Services LLC). Additionally, severely dehydrated calves (skin tent test for more than $3 \mathrm{~s},>8 \%$ ) were administered with intravenous lactated Ringer's solution (VETone, Sypharma Pty. Ltd.). Also, for calves diagnosed with bloat and bloody diarrhea, signs consistent with a clostridial infection, based upon the farm veterinarian's examination, 5 intramuscular doses of penicillin $\mathrm{G}$ procaine suspension, $24 \mathrm{~h}$ apart (Pro-Pen-G, Bimeda Inc.) were administered. Calves with respiratory problems were identified by difficulty breathing, coughing, fever, and the appearance of nasal discharge. Calves were treated with enrofloxacin (Baytril 100, Bayer HealthCare LLC, Animal Health Division) for 3 d. If there was no significant improvement, $72 \mathrm{~h}$ after the first treatment, 1 intramuscular dose of florfenicol (Nuflor, Merck \& Co.) was administered.

\section{Apparent Total-Tract Nutrient Digestibility, Fecal, and Feed Analyses}

During the pre- $(14.9-17.9$ DOA, SD $=1.1 \mathrm{DOA})$ and postweaning periods $(51.0-54.0 \mathrm{DOA}, \mathrm{SD}=1.1$ DOA), a subset ( $\mathrm{n}=8 /$ treatment per season) of calves were used to determine the apparent digestibility of nutrients, using chromic oxide as the external marker. Data reported by Hill et al. (2016b) and Chapman et al. (2016) were used to calculate sample size. A sample size of 7 calves per treatment was calculated based on the digestibility of MR organic matter ( 82.9 vs. $89.1 \%$, respectively, $\mathrm{SD}=3.2 \%$ ) from 19 to $23 \mathrm{DOA}$ of calves fed 0.58 or $1.04 \mathrm{~kg}$ of MR per day (Hill et al., 2016b), using a level of significance of 0.05 and $90 \%$ power. A sample size of 5 calves per treatment was calculated based on the digestibility of calf starter organic matter (78.2 vs. $67.9 \%$, respectively, $\mathrm{SD}=3.7 \%$ ) after weaning of calves fed 0.66 or $0.87 \mathrm{~kg}$ of MR per day (Chapman et al., 2016), using a level of significance of 0.05 and $90 \%$ power. Therefore, a sample size of 8 calves per treatment should provide sufficient power.

Starting $5 \mathrm{~d}$ before and until the end of fecal sampling, calves received $1.18 \mathrm{~g}$ (preweaning period) or $2.35 \mathrm{~g}$ of DM (postweaning period) of $\mathrm{Cr}_{2} \mathrm{O}_{3}$ (Fisher Scientific) per day. The amount of $\mathrm{Cr}_{2} \mathrm{O}_{3}$ were equally divided into 2 portions that were delivered orally in gelatin capsules using a bolus gun (Torpac Inc.) at 1000 and $2200 \mathrm{~h}$ each day. Eight fecal grab samples per calf were collected via rectal palpation to accommodate 3-h intervals of the day $(0000,0300,0600,0900,1200$, 1500,1800 , and $2100 \mathrm{~h}$ ) by advancing $3 \mathrm{~h}$ each day (i.e., 0900 and $2100 \mathrm{~h}$ on d 1, 1200 and $0000 \mathrm{~h}$ on d 2, 1500 and $0300 \mathrm{~h}$ on $\mathrm{d} 3,1800$ and $0600 \mathrm{~h}$ on $\mathrm{d} 4$ ) over a 4-d period. Samples of MR, starter, and orts were collected twice daily (0700 and $1400 \mathrm{~h}$ ) on days that fecal samples were collected and were placed in a forced-air oven at $55^{\circ} \mathrm{C}$ for $48 \mathrm{~h}$ to determine DM. Dry samples (starter, orts, and feces) were pooled by calf and ground to pass through a $1-\mathrm{mm}$ screen. Concentrations of ash (method 942.05; AOAC International, 
2005), CP (method 990.03; AOAC International, 2005), NDF determined using amylase and corrected for ash (aNDFom; method 2002.4 + burning of fibrous residue at $550^{\circ} \mathrm{C}$ for $2 \mathrm{~h}$; AOAC International, 2002), crude fat (method 954.02; AOAC International, 2005), starch (method 2014.10; Hall, 2015), and sugars (DuBois et al., 1956) were determined at the research laboratory in the Department of Animal and Dairy Science on the University of Gerogia Tifton campus. Chemical analysis of MR samples was performed at Cumberland Valley Analytical Services (Waynesboro, PA). Samples of MR were analyzed for DM, OM, CP, and acid hydrolysis fat. Fecal $\mathrm{Cr}_{2} \mathrm{O}_{3}$ concentrations were analyzed as described by Fenton and Fenton (1979) at the Agricultural and Environmental Services Laboratory of the University of Georgia (Athens, GA). The ratio technique using chromic oxide as an inert marker was used to estimate apparent nutrient digestibility (DM, OM, CP, crude fat, starch, sugar, and aNDFom).

\section{Acetaminophen Absorption Test, Blood Sampling, and Laboratory Analyses}

Abomasal emptying rate was determined using acetaminophen absorption test in a subset $(\mathrm{n}=10$ /treatment per season) of calves at $20.1 \pm 1.2 \mathrm{DOA}$ (mean $\pm \mathrm{SD}$ ). Studies examining the effects of season, or MR FR or FF, on abomasal emptying rate using acetaminophen absorption test in calves were not available before this experiment was conducted. Thus, the time to reach the maximum plasma concentration of acetaminophen from the acetaminophen absorption test of calves fed 2 $\mathrm{L}$ of cow milk or $2 \mathrm{~L}$ of cow milk containing an oral rehydration therapy (160 vs. $260 \mathrm{~min}$, respectively, SD = 75 min; Constable et al., 2009), which delays abomasal emptying, were used to calculate the animal number. A sample size of 10 calves per treatment was calculated using a level of significance of 0.05 and $80 \%$ power. Following the afternoon feeding $(\sim 1700 \mathrm{~h})$ on the day before the test, a catheter (14-gauge $\times 2^{\prime \prime}$ radio-opaque Surflash i.v. catheter, Ref: SR $\times$ FF1451, Terumo Corporation) was inserted into the jugular vein of each calf. Calves were fed MR mixed with $50 \mathrm{mg} / \mathrm{kg}$ of BW of acetaminophen ( $N$-acetyl-4-aminophenol, Sigma-Aldrich) at the morning feeding. Blood samples were collected through the catheter into evacuated tubes containing sodium fluoride and potassium oxalate (Becton Dickinson) at 15, 30, 60, 90, 120, 150, 180, 210, 240, 270, 300, $330,360,420$, and $480 \mathrm{~min}$ relative to the starting point of MR feeding. Samples were immediately placed on ice and then centrifuged at $1,700 \times g$ at $4^{\circ} \mathrm{C}$ for $30 \mathrm{~min}$ to collect plasma. The first 2 to $3 \mathrm{~mL}$ of blood collected was discarded before each sample, and the catheter was flushed with $3 \mathrm{~mL}$ of sterile saline containing sodium heparin $(10 \mathrm{IU} / \mathrm{mL})$ after each sampling to prevent clotting. Plasma acetaminophen concentrations were determined by colorimetric assay using a commercially available kit (Paracetamol Assay Kit, cat. no. K8001, Cambridge Life Science) with an inter- and intra-assay coefficient of variation of 8.5 and $9.3 \%$, respectively.

\section{Calculation and Statistical Analyses}

A plot of plasma acetaminophen concentration by time was generated for each calf, to determine the actual maximum plasma concentration of acetaminophen (Cmax) and the time to reach the maximum concentration (Tmax). The trapezoidal method was used to calculate the areas under the curves (AUC) between times. The accumulated AUC of acetaminophen were calculated from 0 to $120 \mathrm{~min}, 0$ to $240 \mathrm{~min}$, and 0 to $480 \mathrm{~min}$. The first derivative of Siegel's modified power exponential equation was also used to model the curve of acetaminophen concentration by time, using PROC NLIN of SAS 9.4 (SAS Institute Inc.). The equation was as follows: $\mathrm{C}(\mathrm{t})=\mathrm{m} \times \mathrm{k} \times \beta \times \mathrm{e}^{(-\mathrm{k} \times \mathrm{t})} \times[1$ $\left.\mathrm{e}^{(-\mathrm{k} \times \mathrm{t})}\right]^{(\beta-1)}$, where $\mathrm{C}(\mathrm{t})$ is the plasma acetaminophen concentration at time $\mathrm{t}$, and $\mathrm{m}, \mathrm{k}$, and $\beta$ are constants. The modeled Tmax was calculated using the following equation: $\operatorname{Tmax}=[\operatorname{Ln}(\beta)] / \mathrm{k}$; and the modeled Cmax was calculated based on Cmax $=\mathrm{m} \times \mathrm{k} \times \beta \times$ $\mathrm{e}^{(-\mathrm{k} \times \operatorname{Tmax})} \times\left[1-\mathrm{e}^{(-\mathrm{k} \times \operatorname{Tmax})}\right]^{(\beta-1)}$. The Tmax calculated from the exponential equation is highly correlated with the scintigraphic half-emptying time (a gold standard for measuring gastric emptying by nuclear scintigraphy; Marshall et al., 2005). The $\mathrm{R}^{2}$ for modeled Tmax (0.91) with scintigraphic half-emptying time is higher than the modeled Cmax (0.84), the actual Tmax (0.87), the actual Cmax (0.81), and the actual accumulated AUC at $120 \mathrm{~min}(0.83)$ and $240 \mathrm{~min}(0.80)$ (Marshall et al., 2005).

Data from each season were analyzed separately. Environmental temperature and relative humidity were summarized by the UNIVARIATE procedure of SAS 9.4, and the means \pm standard deviation are reported. Repeated-measures data, including intakes (MR, starter, total DM, fat, CP, ME), ADG, efficiency measures (ADG/intakes), fecal score, and plasma acetaminophen concentration, were averaged on a weekly basis and analyzed by the MIXED procedure of SAS 9.4. Fixed effects included sex, FR, FF, time, and their interactions with calf nested within treatment $(\mathrm{FR} \times \mathrm{FF})$ as a random variable. The changes in growth parameters (BW, hip and withers heights, and body length) were calculated during the preweaning period (wk 2-6, 1 data point per calf), the postweaning period (wk 6-9, 1 data 

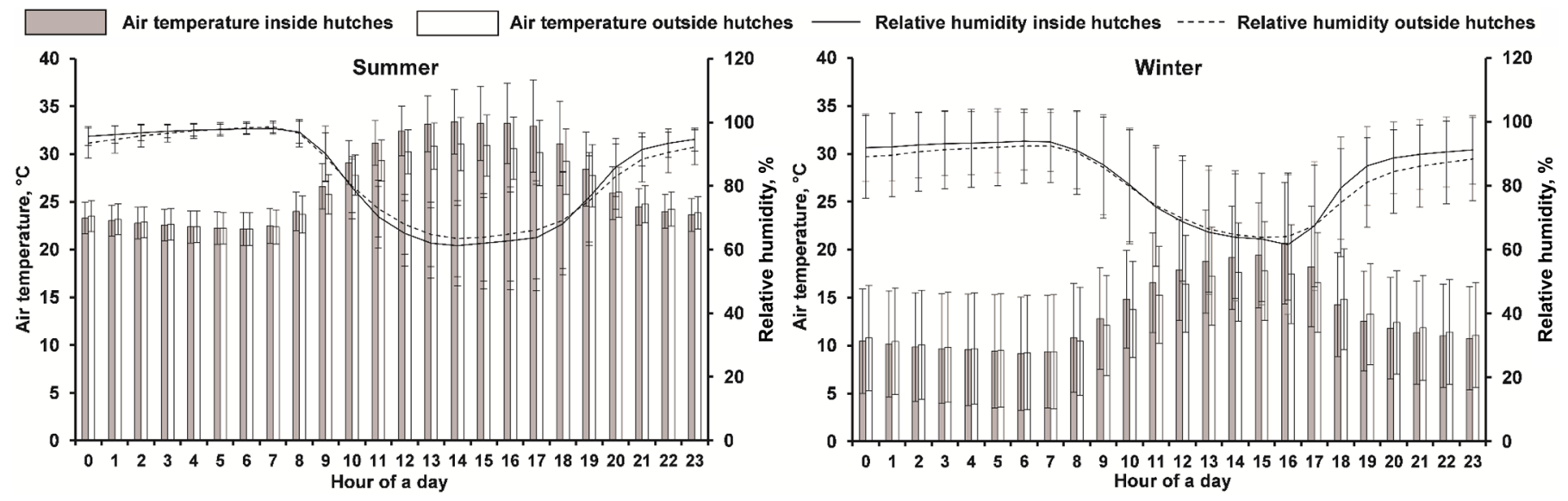

Figure 1. Ambient temperature and relative humidity inside and outside the hutches during summer and winter. Error bars represent SD.

point per calf), and the entire experimental period (wk 2-9, 1 data point per calf). The GLM procedure of SAS 9.4 was used to analyze the changes in growth parameters, apparent total-tract nutrient digestibility within each period (pre- and postweaning), and actual Tmax, Cmax, and AUC, and modeled Tmax and Cmax following acetaminophen ingestion. The model included sex, $\mathrm{FR}, \mathrm{FF}$, and their interactions. Least squares means \pm standard error of the mean are presented. The incidences of diseases were computed using the PROC FREQ procedure of SAS. Binary variables were analyzed by logistic regression using the LOGISTIC procedure of SAS 9.4. The original models included FR, FF, sex, and FF by FR interaction. The interactions between $\mathrm{FF}$ and $\mathrm{FR}$ and sex were not significant $(P>0.10)$ and were then excluded from the final model. The odds ratio and the $95 \%$ confidence interval were calculated and reported. Significance and tendency were declared when $P \leq 0.05$ and $0.05<P \leq 0.10$, respectively.

\section{RESULTS}

\section{Environments, Rectal Temperature, Respiration Rate, and Health}

Chemical analyses of MR and calf starter are detailed in Table 1. The CP and fat concentration of MR as percentage of DM used in summer and winter averaged 27.98 and $19.01 \%$, and 26.22 and $18.37 \%$, respectively. During summer, the calf starter provided (on a DM basis) $17.8 \% \mathrm{CP}, 4.1 \%$ fat, $19.7 \%$ aNDFom, and $3.0 \mathrm{Mcal} /$ $\mathrm{kg}$ of ME. During winter, the calf starter provided (on a DM basis) $18.4 \%$ CP, $4.2 \%$ fat, $18.1 \%$ aNDFom, and 3.0 $\mathrm{Mcal} / \mathrm{kg}$ of ME. During summer, the average environmental temperature and relative humidity were 26.14 $\pm 2.24^{\circ} \mathrm{C}$ and $83.85 \pm 7.78 \%$ outside the hutch, and
$26.98 \pm 2.54^{\circ} \mathrm{C}$ and $83.35 \pm 7.57 \%$ inside the hutch, respectively (Figure 1). The environmental temperature and relative humidity during the winter averaged 12.85 $\pm 5.42^{\circ} \mathrm{C}$ and $81.54 \pm 15.18 \%$ outside the hutch, and $13.27 \pm 5.56^{\circ} \mathrm{C}$ and $83.00 \pm 14.00 \%$ inside the hutch, respectively (Figure 1). During summer, regardless of FR, increasing FF from $2 \times$ to $3 \times$ per day reduced $(P \leq$ $0.01)$ respiration rate from wk 3 to 6 of age $(\mathrm{FF} \times$ time interaction: $P=0.01$; Table 2, Figure 2A) and lowered $(P<0.01)$ the rectal temperature of calves at wk 3 of age $(\mathrm{FF} \times$ time interaction: $P=0.02$; Table 2 , Figure $2 \mathrm{~B})$. In contrast, increasing $\mathrm{FF}$ reduced rectal temperature $\left(39.12\right.$ vs. $39.02^{\circ} \mathrm{C}, \mathrm{SEM}=0.03^{\circ} \mathrm{C}$, for calves fed MR $2 \times$ and $3 \times$ per day, respectively, $P=0.05)$ but did not affect respiration rate in the winter (Table 2).

During summer, we found an FR $\times \mathrm{FF} \times$ time interaction $(P<0.01)$ for fecal score observed at 2 to $3 \mathrm{wk}$ of age. This was because low $2 \times$ calves had higher fecal scores than high $3 \times$ calves at wk 2 of age, but low $2 \times$ calves had higher fecal score than low $3 \times$ calves at wk 3 of age (Figure $3 \mathrm{~A})$. An FR $\times$ time interaction $(P=$ $0.03)$ was observed during winter for fecal score because calves fed high diets had higher fecal scores than those fed low diets at wk 5 after birth (Figure 3B). Treatment had no effect on the incidences of scours, pneumonia, or morbidity rates in both seasons $(P \geq 0.16$, Table 3$)$.

\section{Intake and Growth}

Consistent with the experimental design, calves on the high treatments consumed more MR than calves on the low diets in both seasons $(P<0.01$, Table 4$)$. No difference was observed in intake due to $\mathrm{FF}(P>0.10)$ during the summer; however, we found a trend for an interaction of $\mathrm{FR}$ and $\mathrm{FF}(P=0.08)$ for MR intake, such that increasing FF from $2 \times$ to $3 \times$ per day tended 

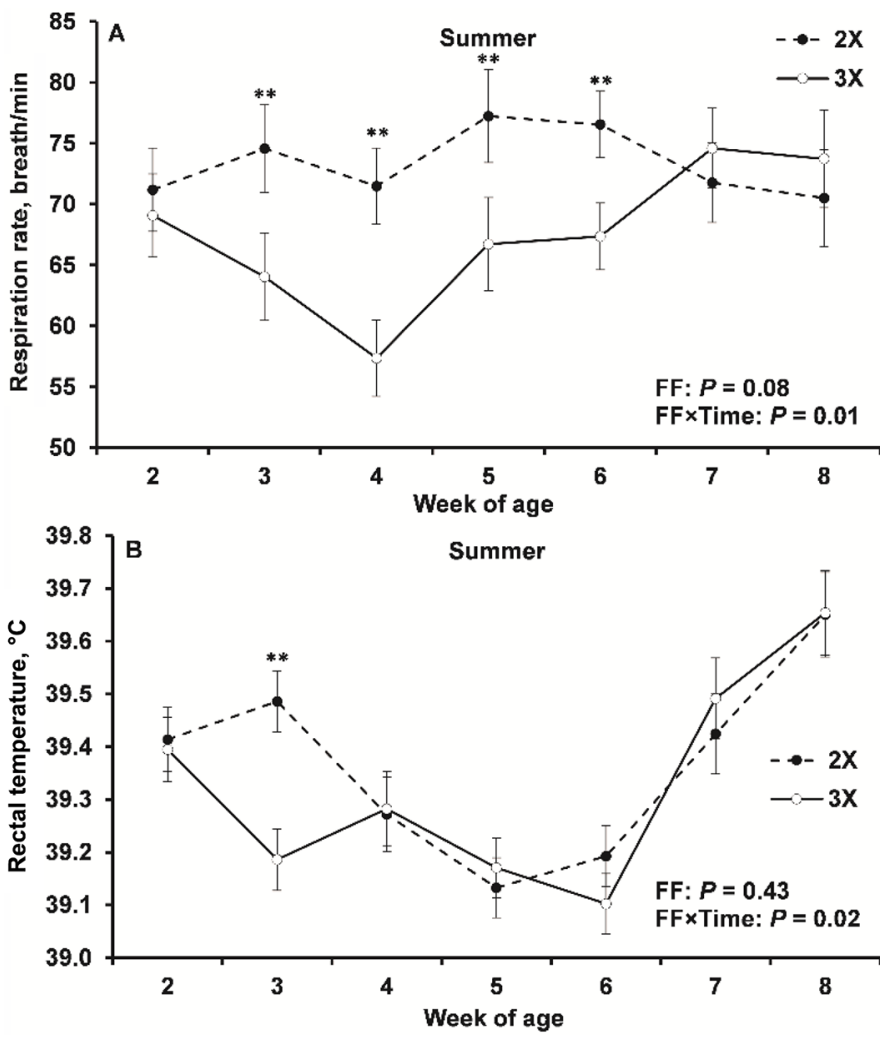

Figure 2. Milk replacer feeding rate $[0.65 \mathrm{~kg}$ of $\mathrm{DM} / \mathrm{d}$ of a milk replacer containing $26 \% \mathrm{CP}$ and $17 \%$ fat (low, $\mathrm{n}=24$ ) vs. $0.76 \mathrm{~kg}$ of $\mathrm{DM} / \mathrm{d}$ of a milk replacer containing $26 \% \mathrm{CP}$ and $17 \%$ fat (high, $\mathrm{n}=$ $24)]$ and feeding frequency $[\mathrm{FF}$, twice $(2 \times, \mathrm{n}=24)$ vs. 3 times per day $(3 \times, \mathrm{n}=24)]$ on respiration rate and rectal temperature during summer. Errors bars represent SEM; ${ }^{* *} P \leq 0.01$.

$(P=0.06)$ to increase MR intake for low calves but not for high calves (Table 4). In contrast, during the winter, high calves fed $2 \times$ daily consumed more $(P<0.01)$ MR than $3 \times$ per day, but FF did not $(P=0.90)$ affect MR intake of calves fed low, resulting in an interaction between FR and FF ( $P=0.02$; Table 4$)$.

During summer, we observed interactions of $\mathrm{FF} \times$ time $(P=0.05)$ and $\mathrm{FR} \times$ time $(P=0.07)$ for starter intake. Compared with calves fed MR $2 \times$ a day, calves fed $3 \times$ daily had higher starter intake at wk 8 and 9 of age (Figure 4A). Regardless of FF, calves fed high had lower starter intake than low at wk 7 of age (Figure $4 \mathrm{C})$. The altered starter intake by FF and FR resulted in similar $\mathrm{FF} \times$ time $(P=0.08)$ and $\mathrm{FR} \times$ time $(P$ $<0.01$ ) interactions for DMI during summer (Table 4, Figure 4B, D). Milk replacer FF or FF $\times$ time did not affect calves' $\mathrm{CP}$ and fat intakes during summer. In contrast, the $\mathrm{CP}$ intake of calves fed high tended to be greater at wk 3 and 4 but was lower at wk 7 of age compared with low $(\mathrm{FR} \times$ time interaction, $P<$ 0.01 , Figure 5A). Similarly, calves fed high maintained greater fat intake from wk 3 to 6 of age than those

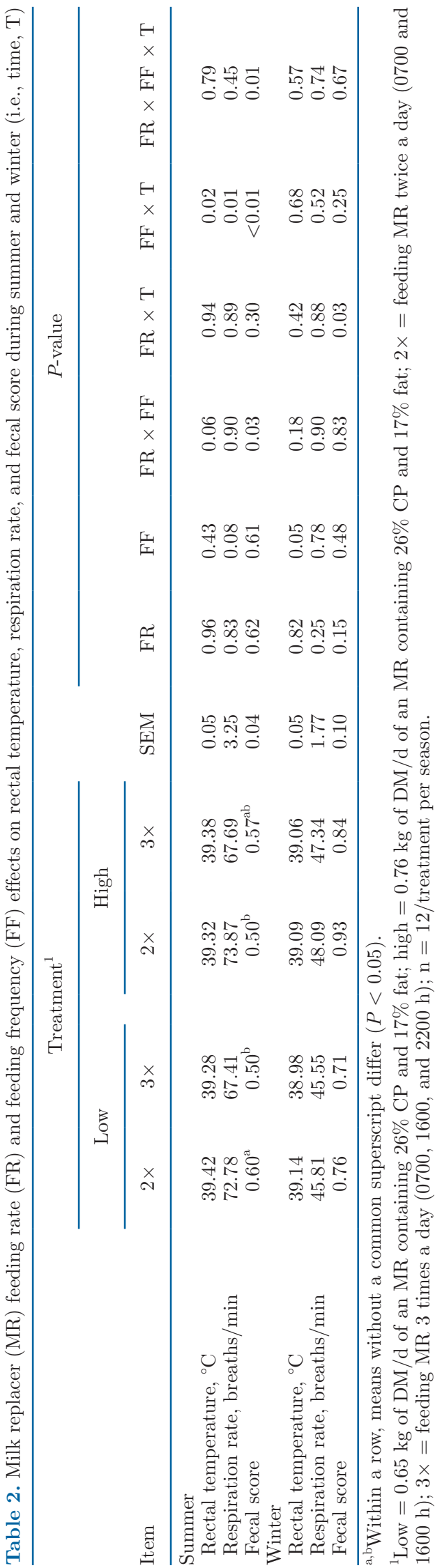



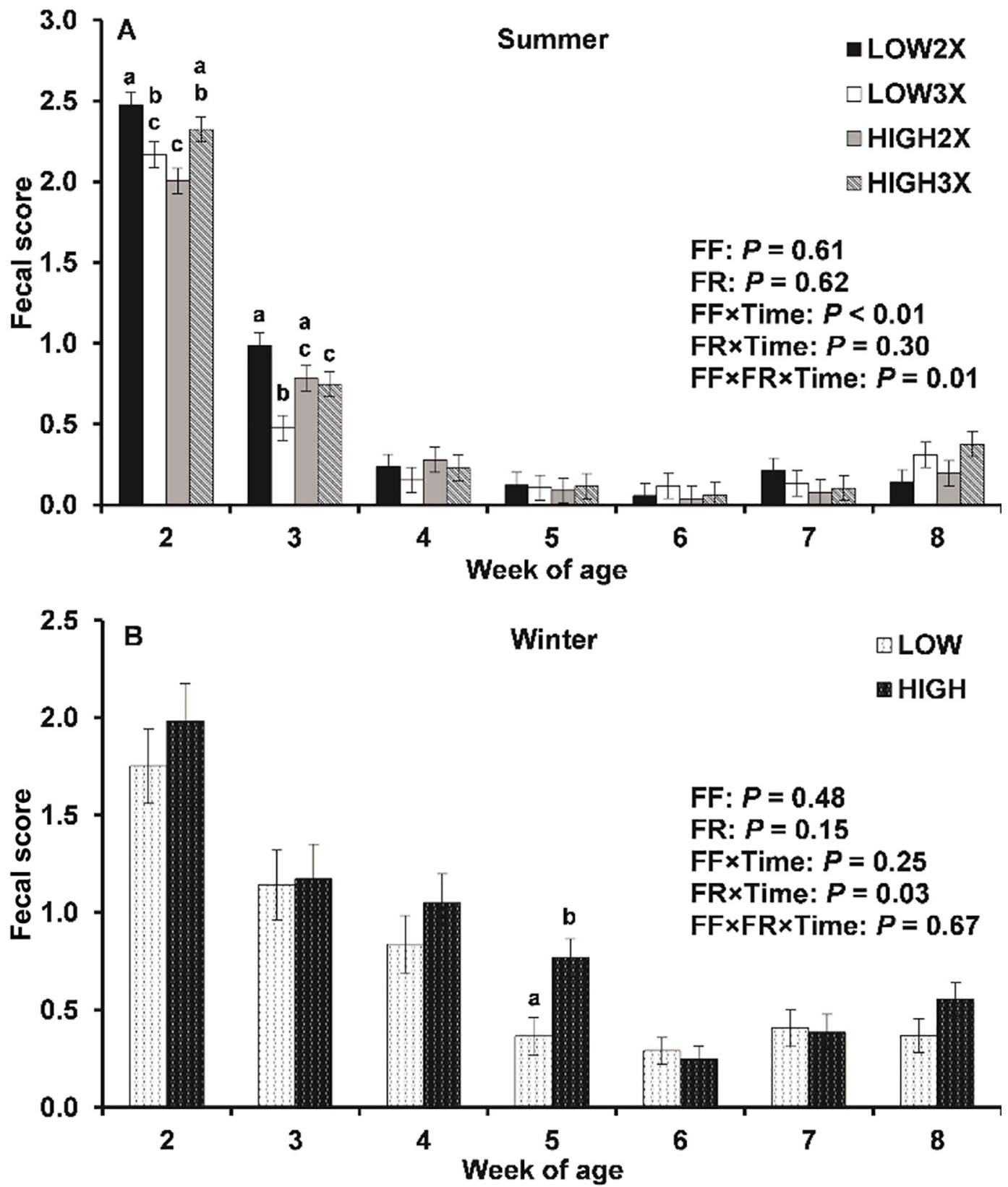

Figure 3. Milk replacer feeding rate [FR, $0.65 \mathrm{~kg}$ of DM/d of a milk replacer containing $26 \% \mathrm{CP}$ and $17 \%$ fat (low, $\mathrm{n}=24 / \mathrm{season})$ vs. 0.76 $\mathrm{kg}$ of DM/d of a milk replacer containing $26 \% \mathrm{CP}$ and $17 \%$ fat (high, $\mathrm{n}=24 /$ season)] and frequency (FF, twice $[2 \times, \mathrm{n}=24 /$ season] vs. 3 times per day $[3 \times, \mathrm{n}=24 /$ season] $)$ on fecal score during summer and winter. Errors bars represent SEM. Within a week, means without a common letter differ $(P<0.05)$.

fed low $(\mathrm{FR} \times$ time interaction, $P<0.01$, Figure $5 \mathrm{C})$ during summer. Both $\mathrm{FF} \times$ time $(P=0.06)$ and FR $\times$ time $(P=0.04)$ interactions were observed for $\mathrm{ME}$ intake during summer. Compared with low, calves fed high had greater ME intake from wk 3 to 5 of age but tended to have a lower ME intake at wk 7 of age (Figure $5 \mathrm{~B})$. Relative to $2 \times$, feeding MR $3 \times$ a day supported greater ME intake at wk 5 and 9 and tended to support greater ME intake at wk 4 and 8 of age (Figure 5D).
During winter, FR or its interaction with time had no $(P \geq 0.17)$ effects on intakes of starter, DMI, CP, and ME (Table 4). However, calves fed high had greater fat intake from wk 2 to 6 of age compared with those fed low $(\mathrm{FR} \times$ time interaction: $P<0.01$, Figure $6 \mathrm{~A})$. Regardless of FR, feeding MR $3 \times$ per day increased $(P \leq 0.05)$ the intake of starter and $\mathrm{CP}$ and tended to increase $(P=0.07)$ the intake of DM during the experimental period compared with those fed $2 \times$ daily 


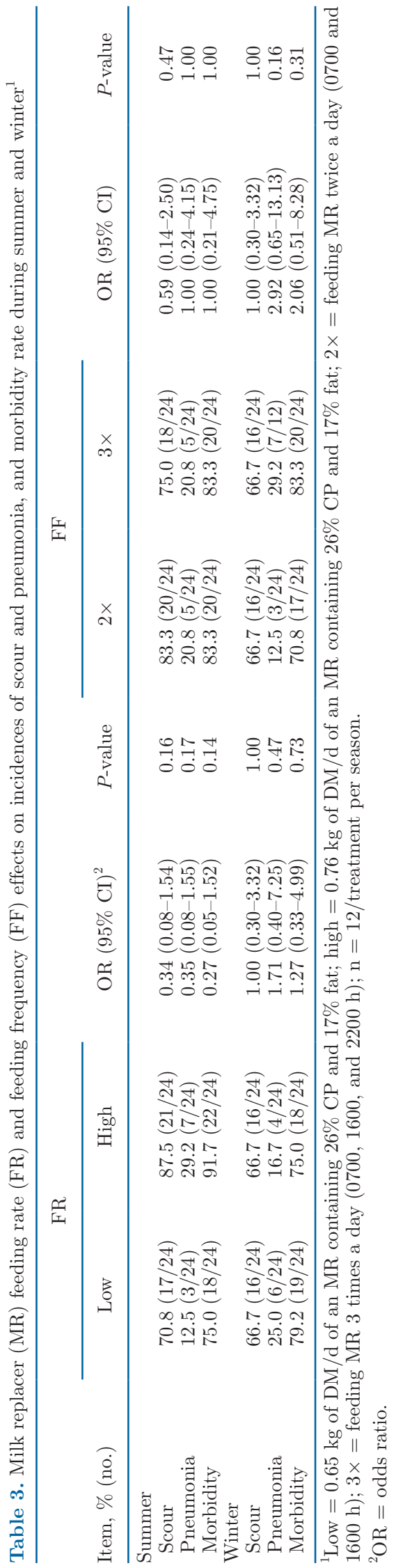

during winter (Table 4). Additionally, we observed was a tendency $(P=0.09)$ of $\mathrm{FF} \times$ time interaction for $\mathrm{ME}$ intake, because calves fed $3 \times$ daily had greater $\mathrm{ME}$ intake at wk 5 and 6 , and tended to have greater ME intake at wk 9 of age compared with those fed $2 \times$ a day (Figure 6B).

Relative to low, feeding the high diet increased $(P \leq$ $0.02)$ gains in BW, hip height, and body length from wk 2 to 6 of age during summer (Table 5). Regardless of FR, during summer, increasing FF from $2 \times$ to $3 \times$ tended $(P=0.10)$ to increase the gain in hip height from 2 to 6 wk of age. During the postweaning period (wk 6-9 of age), FF, FR, and their interaction had no $(P>0.10)$ effect on growth in the summer. During winter, the high diet tended to support greater $(P=$ $0.07)$ ADG and body length gain and supported greater $(P \leq 0.02)$ gains in BW and hip height compared with low from wk 2 to 9 of age (Table 5). Additionally, calves fed high had greater $(P \leq 0.07)$ gains in BW and body length from wk 2 to 6 of age during winter. In contrast to summer, feeding MR $3 \times$ daily in the winter tended $(P \leq 0.09)$ to increase ADG and gains in BW and wither height during the experimental period compared with $2 \times$ per day. Feeding MR more frequently also tended to support greater $(P=0.07) \mathrm{BW}$ gain during the preweaning period and supported greater $(P=0.04)$ gain in withers height during the postweaning period (Table 5). Compared with low, feeding high increased $(P \leq 0.10)$ ADG/DMI, ADG/CP, and ADG/ $\mathrm{ME}$ in both summer and winter (Tables 4). However, FF did not affect efficiency measures in both seasons, regardless of FR (Table 4).

\section{Apparent Digestibility Test and Acetaminophen Pharmacokinetics}

During summer, no differences were observed in apparent nutrient digestibility $(P \geq 0.12$; Table 6$)$ among treatment during the preweaning or postweaning periods, except that postweaning fat digestibility tended to be greater $(P=0.10)$ for calves fed high compared with those fed low. In the winter, an interaction of $\mathrm{FF}$ and FR $(P=0.06)$ was observed for fat digestibility during both pre- and postweaning periods. This was because fat digestibility for calves fed high, but not low, tended to be higher $(P=0.10)$ before weaning, but was lower $(P=0.08)$ after weaning when FF increased from $2 \times$ to $3 \times$ daily.

Increasing MR FF from $2 \times$ to $3 \times$ daily lowered $(P$ $<0.01$ ) both modeled and actual Tmax of plasma acetaminophen during both summer and winter (Table 7; Figure 7). Additionally, greater $(P \leq 0.09)$ Cmax and accumulated AUC from either 0 to 120 or 0 to $240 \mathrm{~min}$ of plasma acetaminophen following MR ingestion were 


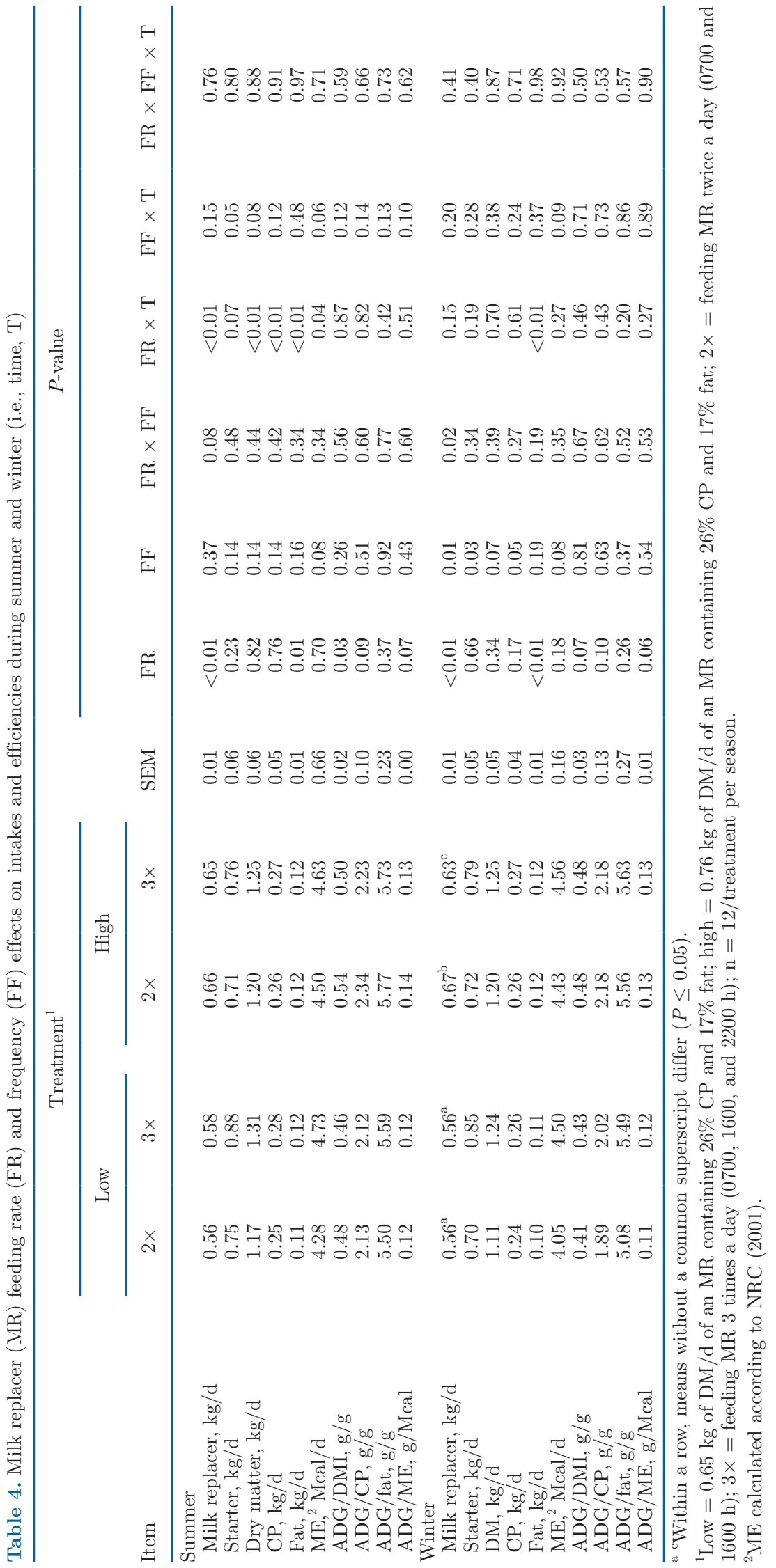



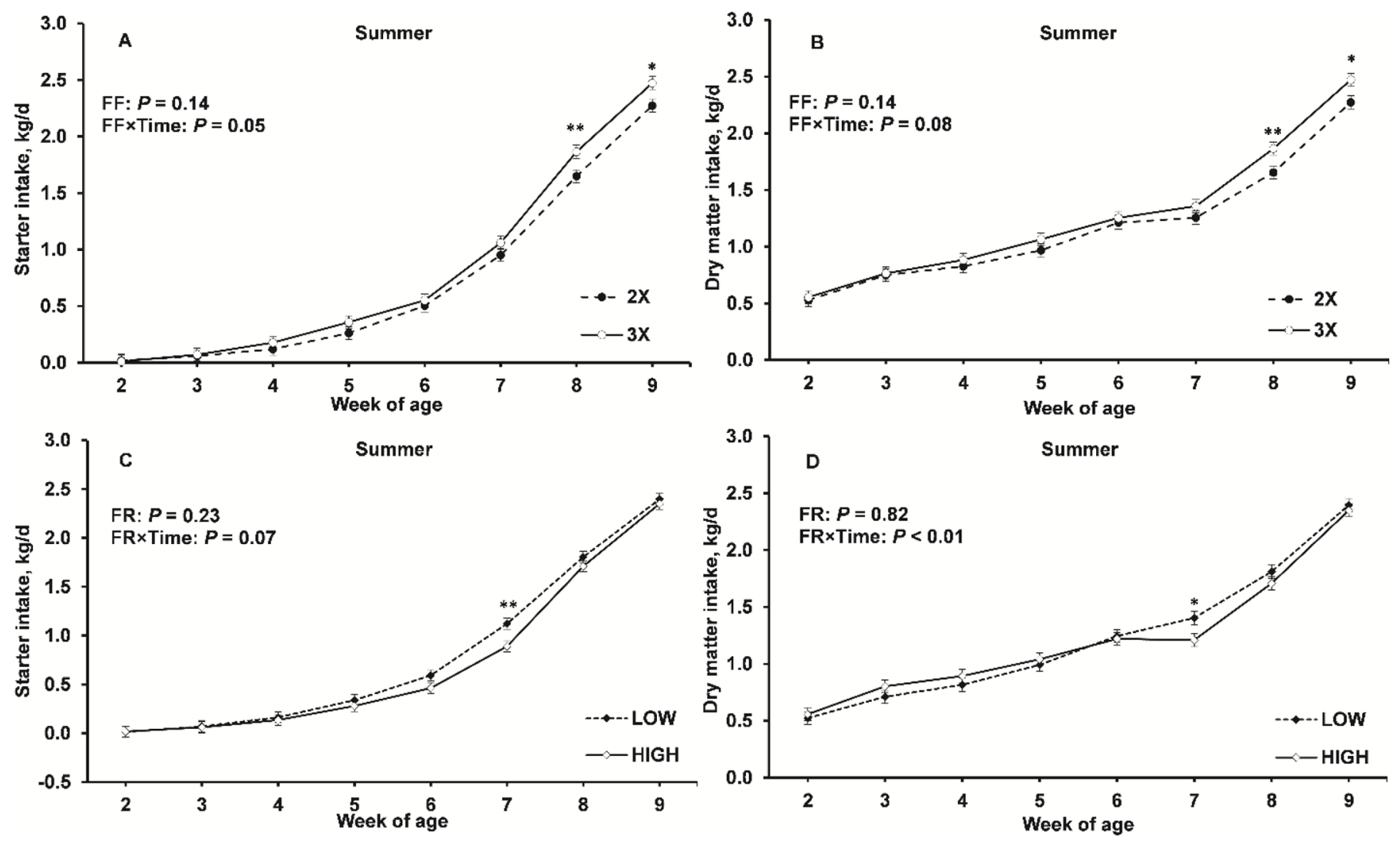

Figure 4. Milk replacer feeding rate $[\mathrm{FR}, 0.65 \mathrm{~kg}$ of DM/d of a milk replacer containing $26 \% \mathrm{CP}$ and $17 \%$ fat (low, $\mathrm{n}=24) \mathrm{vs} .0 .76 \mathrm{~kg}$ of $\mathrm{DM} / \mathrm{d}$ of a milk replacer containing $26 \% \mathrm{CP}$ and $17 \%$ fat (high, $\mathrm{n}=24)]$ and frequency $[\mathrm{FF}$, twice $(2 \times, \mathrm{n}=24)$ vs. 3 times per day $(3 \times, \mathrm{n}=$ $24)$ ] on starter intake and dry matter intake during summer. Errors bars represent SEM; ${ }^{* *} P \leq 0.01,{ }^{*} P \leq 0.05$.

observed for calves fed $3 \times$ compared with $2 \times$ daily in both seasons (Table 7; Figure 7). These data indicate accelerated abomasal emptying by increasing FF. In the summer, calves fed high tended $(P \leq 0.10)$ to have greater actual or modeled Tmax but tended $(P \leq 0.08)$ to have lower actual or modeled Cmax and had lower $(P$ $=0.04$ ) accumulated AUC from 0 to 240 min of plasma acetaminophen compared with calves fed low (Table 7; Figure 7). In the winter, calves fed high tended $(P=$ 0.07) to have higher actual Cmax of plasma acetaminophen, but no $(P \geq 0.28)$ differences were observed for other parameters compared with calves fed low (Table 7; Figure 7).

\section{DISCUSSION}

Calves reared during summer are exposed to a challenging environment, partially because of heat stress conditions. Calves increase respiration and sweating rates when ambient temperature exceeds $20^{\circ} \mathrm{C}$ (Gebremedhin et al., 1981). In our current experiment, the ambient temperature during the summer was con- sistently higher than $20^{\circ} \mathrm{C}$ during the day, and calves had considerably higher average rectal temperatures $\left(39.35^{\circ} \mathrm{C}\right)$ and respiration rates $(70$ breaths/min). Normal rectal temperature of calves in thermal neutral condition is $38.5^{\circ} \mathrm{C}$ (Collier et al., 2019). These changes confirmed that calves were experiencing heat stress. Although lower than summer, calves reared during the winter had an average rectal temperature $\left(39.07^{\circ} \mathrm{C}\right)$ higher than $38.5^{\circ} \mathrm{C}$ as well. These data suggest that calves raised during the winter also experience some degree of heat stress and carried additional heat load. During the winter phase of the experiment (134 d), the average ambient temperature exceeded $20^{\circ} \mathrm{C}$ on $12 \mathrm{~d}$, and $48 \mathrm{~d}$ had maximal ambient temperature exceeding $20^{\circ} \mathrm{C}$. Therefore, during the winter within the southeastern United States, calves were not exposed to traditional cold stress. This weather pattern represents the normal climate in the Southeast region. Additionally, calves' body temperature exhibits a diurnal pattern, with greater body temperature in the afternoon than in the morning (Piccione et al., 2003; Hill et al., 2016a). In the current study, the rectal temperature was measured 
at $\sim 1430 \mathrm{~h}$, which would not represent the daily average body temperature. Techniques that continuously measure body temperature within a day would provide a better evaluation of calves' thermal status and should be considered for future studies.

During summer, compared with $2 \times$, feeding $3 \times$ daily reduced respiration rate during the preweaning period and reduced rectal temperature at wk 3 of age. Similarly, during winter, increasing FF lowered calves' rectal temperature. These data indicate that increasing FF lowers heat load. This may be due to reduced metabolic heat production, increased heat dissipation, or both. Indeed, van den Borne et al. (2006) reported that feeding veal calves $4 \times$ compared with $2 \times$ a day reduced heat production on a metabolic $\mathrm{BW}$ basis, regardless of intake.

As expected, increasing FF substantially accelerated abomasal emptying in both seasons because of reduced meal size. MacPherson et al. (2016) reported that increasing FR from 0.6 to $1.2 \mathrm{~kg}$ of solid per day reduced abomasal emptying rate under non-heat stressed conditions. In contrast, FR had no effect on abomasal emptying rate during winter. This suggested that the small increase in meal size was not a limiting factor for abomasal emptying in winter. However, increasing FR tended to delay abomasal emptying during summer. Heat stress limits gastric motility in dairy cattle and was reported to reduce the rate of passage for lactating dairy cows and prepubertal heifers compared with those under thermal neutrality (McDowell et al., 1969; Nonaka et al., 2008). Our results suggest that heat stress may also delay abomasal emptying in preweaning calves when FR is increased. It is worth noting that other stressors, such as diarrhea, have also been reported to delay abomasal emptying in calves (Kirchner et al., 2015; Hildebrandt et al., 2017).

Consistent with the experimental design, in both seasons calves fed high had higher MR intake supporting either statistically or numerically greater $\mathrm{CP}$, fat, and ME intakes compared with low during the preweaning period. In contrast with previous studies conducted in a temperate environment (Quigley et al., 2018; Dennis et al., 2019), which reported reduced starter intake when FR was increased, in our current experiment FR did not affect starter intake during winter, and low supported greater starter intake only at 7 wk of age
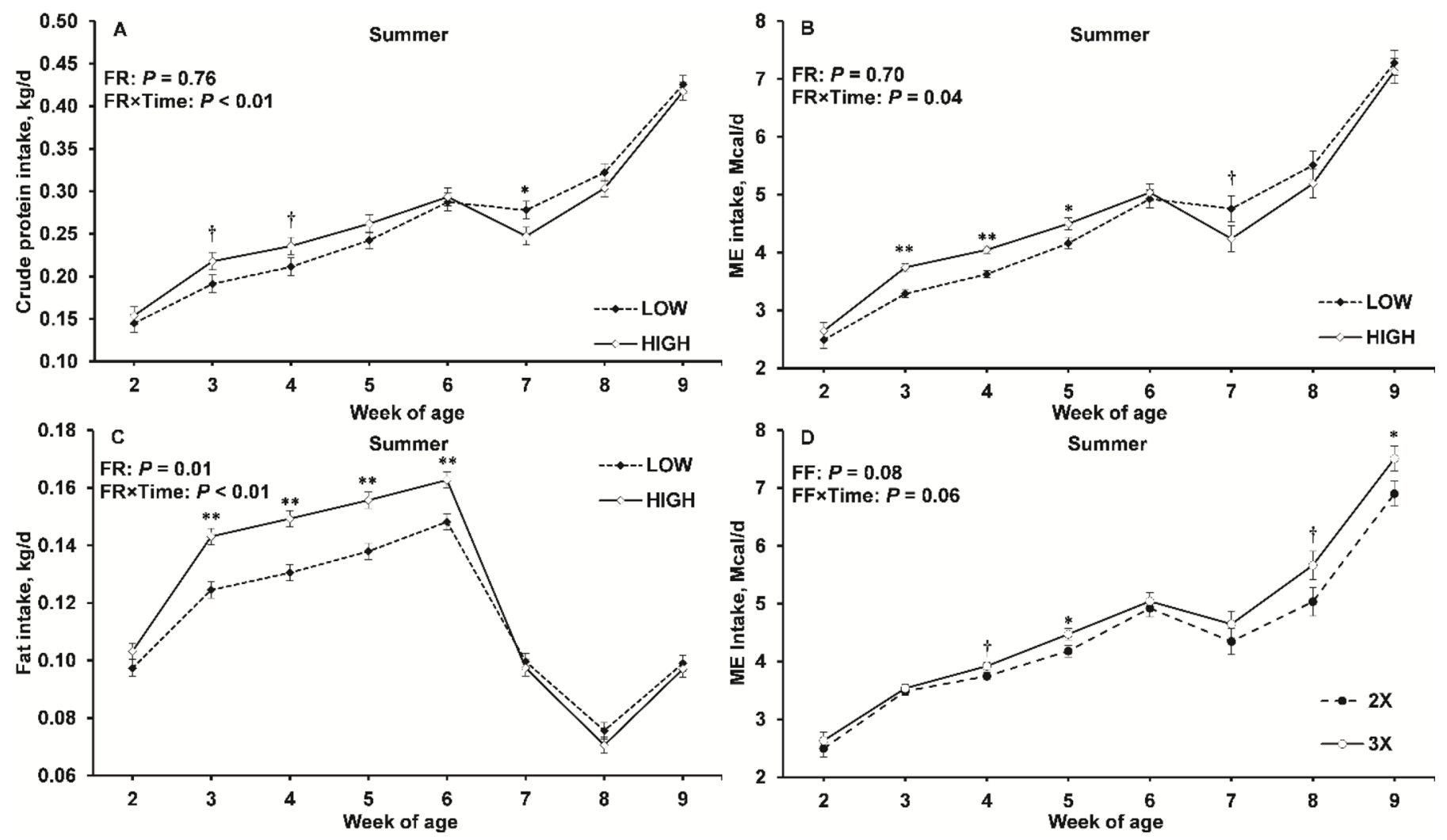

Figure 5. Milk replacer feeding rate $[\mathrm{FR}, 0.65 \mathrm{~kg}$ of DM/d of a milk replacer containing $26 \% \mathrm{CP}$ and $17 \%$ fat (low, $\mathrm{n}=24) \mathrm{vs} .0 .76 \mathrm{~kg}$ of $\mathrm{DM} / \mathrm{d}$ of a milk replacer containing $26 \% \mathrm{CP}$ and $17 \%$ fat (high, $\mathrm{n}=24)]$ and frequency $[\mathrm{FF}$, twice $(2 \times, \mathrm{n}=24)$ vs. 3 times per day $(3 \times, \mathrm{n}=$ $24)$ ] on intakes of crude protein, fat, and ME during summer. Errors bars represent SEM; $* * P \leq 0.01,{ }^{*} P \leq 0.05, \dagger P \leq 0.10$. 

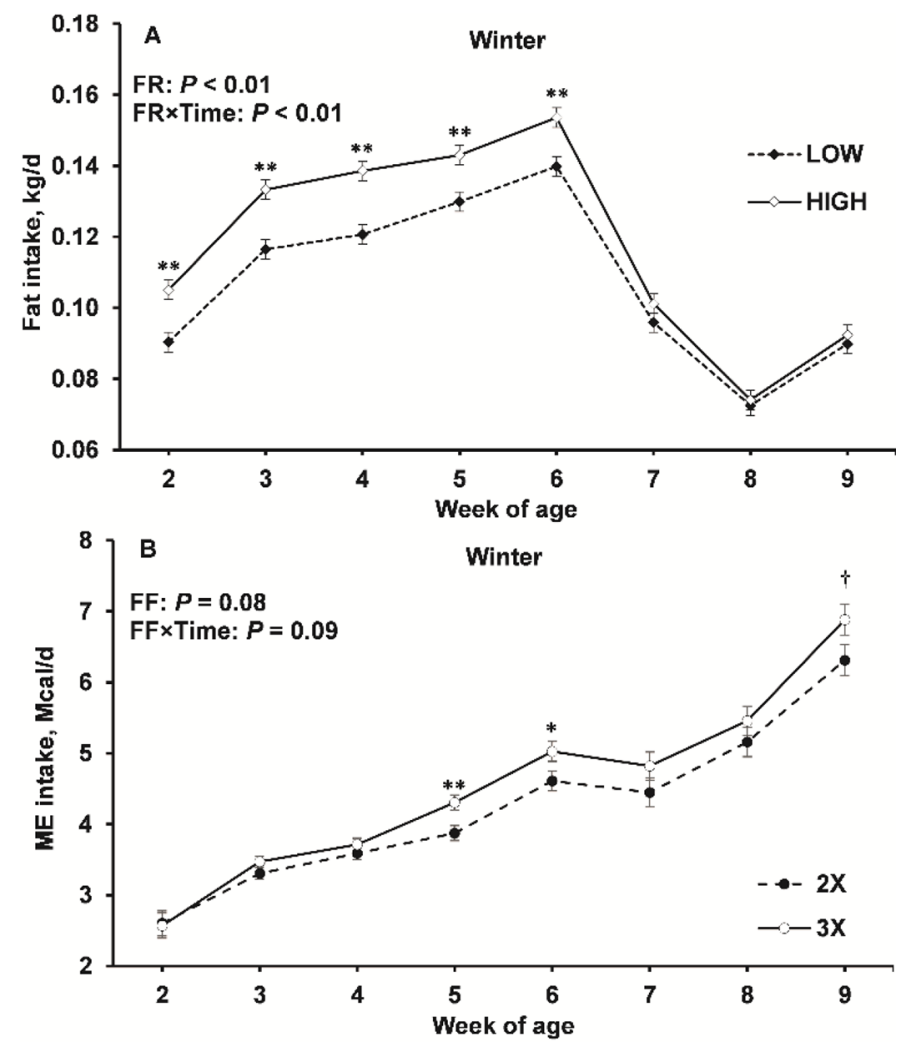

Figure 6. Milk replacer feeding rate $[\mathrm{FR}, 0.65 \mathrm{~kg}$ of $\mathrm{DM} / \mathrm{d}$ of a milk replacer containing $26 \% \mathrm{CP}$ and $17 \%$ fat (low, $\mathrm{n}=24)$ vs. $0.76 \mathrm{~kg}$ of $\mathrm{DM} / \mathrm{d}$ of a milk replacer containing $26 \% \mathrm{CP}$ and $17 \%$ fat (high, $\mathrm{n}=$ $24)]$ and frequency $[\mathrm{FF}$, twice $(2 \times, \mathrm{n}=24)$ vs. 3 times per day $(3 \times, \mathrm{n}$ $=24)$ ] on intakes of fat and ME during winter. Errors bars represent $\mathrm{SEM} ;{ }^{* *} P \leq 0.01,{ }^{*} P \leq 0.05, \dagger P \leq 0.10$

compared with high during summer. Compared with Quigley et al. (2018), who fed 0.66 or $1.07 \mathrm{~kg}$ per day, and Dennis et al. (2019), who fed 0.66 or $0.85 \mathrm{~kg}$ of DM per day, calves in the current study were fed 0.65 and $0.76 \mathrm{~kg}$ of MR per day. The smaller difference in MR allowance may have prevented us from observing significant differences in starter intake. Increasing FR improved preweaning growth in both seasons, likely because of the greater intake of energy and total nutrients. It has been consistently reported that higher FR improves preweaning ADG and skeletal growth by increasing energy and protein intake (Brown et al., 2005; Blair, 2015). However, MR FR did not affect growth performance during the postweaning period. Previous researchers have reported that increasing FR reduces nutrient digestibility provided by grain and alters diurnal feeding pattern postweaning, leading to reduced growth (Miller-Cushon et al., 2013; Quigley et al., 2018; Dennis et al., 2019). In our current study, neither starter intake nor nutrient digestibility after weaning was affected by FR.
Increasing FR improved ADG/DMI regardless of season, consistent with previous studies (Diaz et al., 2001; Brown et al., 2005; Bartlett et al., 2006). The greater $\mathrm{ADG} / \mathrm{DMI}$ is a result of the larger dilution effect of maintenance cost of the calf (Diaz et al., 2001; Bartlett et al., 2006; van den Borne et al., 2006). In both seasons, calves fed high had greater ADG/CP and ADG/ ME but similar ADG/fat compared with those fed low. Similarly, we previously reported that preweaning ADG had the lowest correlation with total fat intake compared with total DM, CP, and ME intakes during summer (Orellana Rivas et al., 2020). These data indicate the importance of dietary intake of ME and protein for improving growth of dairy calves. However, the increased ME intake required for greater ADG cannot be achieved by increasing fat content of the MR. Hill et al. (2009) reported that calves fed $0.66 \mathrm{~kg}$ of DM per day of MR containing $27 \% \mathrm{CP}$ with different fat concentrations (14-23\%) had similar feed efficiency during both pre- and postweaning periods.

Reported results with regard to the effect of milk or MR FF on starter intake and growth of dairy calves are inconsistent. An early study reported that feeding whole milk $2 \times$ a day at $450 \mathrm{~g}$ of solid per day increased starter intake and BW gain pre- but not postweaning, compared with $1 \times$ per day (Schingoethe et al., 1986). In contrast, Stanley et al. (2002) fed an MR containing $22 \% \mathrm{CP}$ and $15 \%$ fat at $10 \%$ of initial BW at the beginning of the trial either $1 \times$ or $2 \times$ daily, and reported that $\mathrm{FF}$ had no effect on starter intake or growth. Compared with $2 \times$ a day, feeding $4 \times$ daily had no effect on starter intake when an MR containing $26 \% \mathrm{CP}$ and $18 \%$ fat was fed at $2 \%$ (MR solids) of BW, but increased starter consumption shortly before and during weaning when a 20:20 MR was fed at a rate of $1.5 \%$ of BW (Kmicikewycz et al., 2013). However, growth was not affected by FF regardless of MR composition (Kmicikewycz et al., 2013). Sockett et al. (2011) reported that, compared with $2 \times$ a day, calves fed an MR containing $28 \% \mathrm{CP}$ and $20 \%$ fat $(1.135 \mathrm{~kg}$ of solids/d) $3 \times$ daily increased starter intake during the week of weaning when MR allowance was reduced by half and fed $1 \times$ per day. Increasing $\mathrm{FF}$ improved gains in preweaning BW and hip height (Sockett et al., 2011). In contrast, MacPherson et al. (2019) reported that FF ( 2 vs. $4 \times$ per day) had no effect on starter intake or growth when calves were fed a $26 \% \mathrm{CP}$ and $18 \%$ fat MR at a rate of $1.2 \mathrm{~kg}$ of solid per day and raised on an automated calf feeder. In a recent study, Grice et al. (2020) reported that calves fed an MR containing $25 \%$ $\mathrm{CP}$ and $19 \%$ fat $2 \times$ a day had greater preweaning ADG compared with those fed $3 \times$ a day. However, FF did not affect postweaning growth (Grice et al., 2020). The 


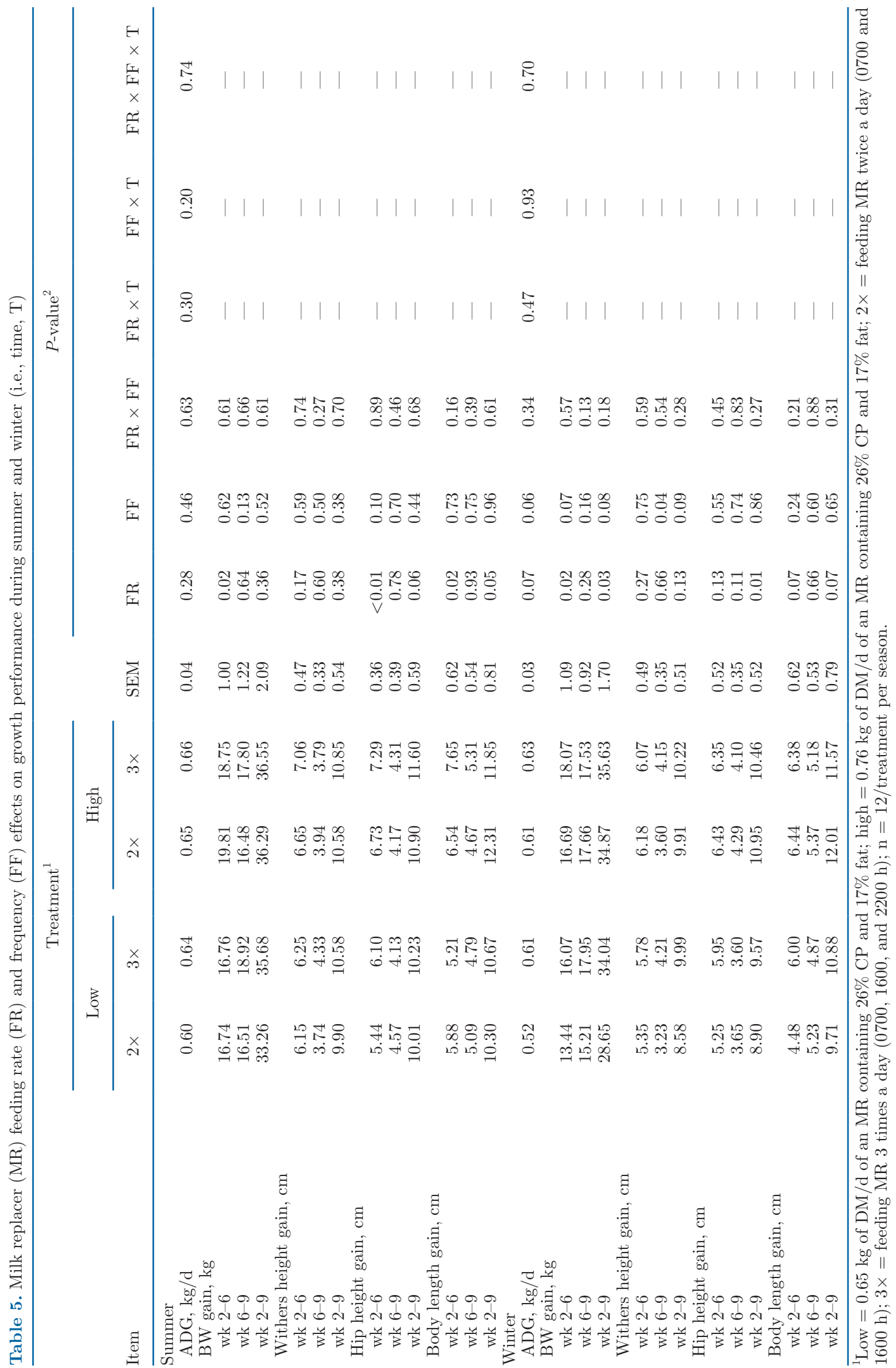




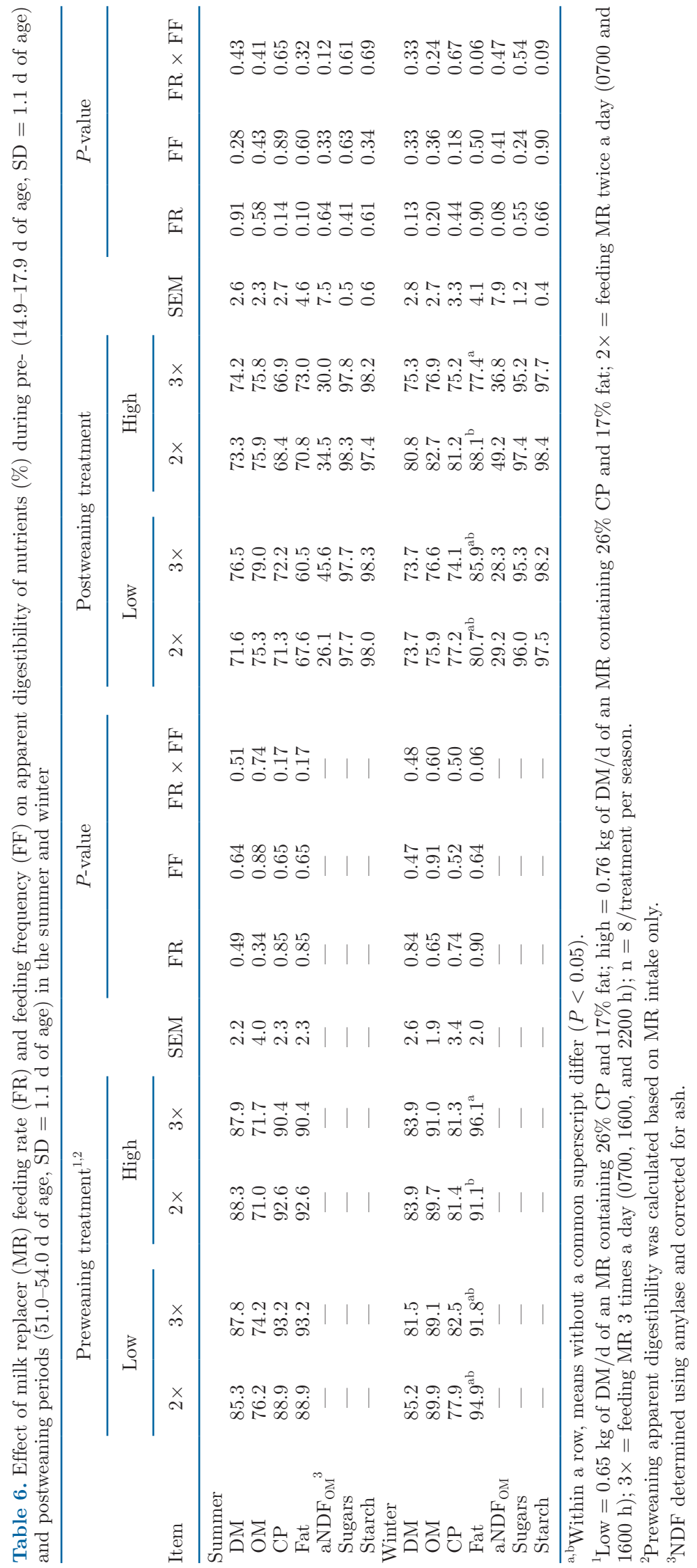


Table 7. Milk replacer (MR) feeding rate (FR) and frequency (FF) effects on actual maximal concentration (Cmax), time to reach Cmax (Tmax), and accumulated area under the curve (AUC) of plasma acetaminophen following morning milk replacer feeding at $20 \mathrm{~d}$ of age during summer and winter ${ }^{1}$

\begin{tabular}{|c|c|c|c|c|c|c|c|c|}
\hline \multirow[b]{3}{*}{ Item } & \multicolumn{4}{|c|}{ Treatment $^{2}$} & \multirow[b]{3}{*}{ SEM } & \multicolumn{3}{|c|}{$P$-value } \\
\hline & \multicolumn{2}{|c|}{ Low } & \multicolumn{2}{|c|}{ High } & & \multirow[b]{2}{*}{ FR } & \multirow[b]{2}{*}{$\mathrm{FF}$} & \multirow[b]{2}{*}{$\mathrm{FR} \times \mathrm{FF}$} \\
\hline & $2 \times$ & $3 \times$ & $2 \times$ & $3 \times$ & & & & \\
\hline \multicolumn{9}{|l|}{ Summer } \\
\hline \multicolumn{9}{|l|}{ Actual } \\
\hline Cmax, mg/L & 21.3 & 23.8 & 19.0 & 21.3 & 1.4 & 0.08 & 0.09 & 0.94 \\
\hline AUC $240 \mathrm{~min}, \mathrm{mg} \times \mathrm{min} / \mathrm{L}$ & 3,603 & 4,223 & 3,135 & 3,669 & 242 & 0.04 & 0.02 & 0.86 \\
\hline AUC $480 \mathrm{~min}, \mathrm{mg} \times \min / \mathrm{L}$ & 7,222 & 7,391 & 6,940 & 6,733 & 311 & 0.14 & 0.95 & 0.55 \\
\hline \multicolumn{9}{|l|}{ Modeled } \\
\hline $\mathrm{Cmax}, \mathrm{mg} / \mathrm{L}$ & 19.2 & 22.2 & 17.3 & 19.6 & 1.2 & 0.07 & 0.04 & 0.77 \\
\hline Tmax, $\min$ & 192.8 & 152.3 & 223.2 & 164.2 & 11.6 & 0.08 & $<0.01$ & 0.43 \\
\hline \multicolumn{9}{|l|}{ Winter } \\
\hline \multicolumn{9}{|l|}{ Actual } \\
\hline \multicolumn{9}{|l|}{ Modeled } \\
\hline $\mathrm{Cmax}, \mathrm{mg} / \mathrm{L}$ & 14.5 & 18.2 & 16.1 & 19.0 & 1.0 & 0.28 & $<0.01$ & 0.71 \\
\hline Tmax, min & 217.0 & 159.3 & 223.0 & 146.8 & 10.6 & 0.76 & $<0.01$ & 0.39 \\
\hline
\end{tabular}

${ }^{1}$ Modeled Cmax and Tmax were obtained by fitting the acetaminophen concentration-time curve to the first derivative of Siegel's modified power exponential equation (Marshall et al., 2005).

${ }^{2} \mathrm{Low}=0.65 \mathrm{~kg}$ of DM/d of an MR containing $26 \% \mathrm{CP}$ and $17 \%$ fat; high $=0.76 \mathrm{~kg}$ of DM $/ \mathrm{d}$ of an MR containing $26 \% \mathrm{CP}$ and $17 \%$ fat; $2 \times=$ feeding MR twice a day $(0700$ and $1600 \mathrm{~h}) ; 3 \times=$ feeding MR 3 times a day $(0700,1600$, and $2200 \mathrm{~h}) ; \mathrm{n}=10 /$ treatment per season.

reasons for the discrepancy among studies include, but are not limited to, MR allowance and composition, and the interval between feedings. Results from our current study suggest that season also influences the response to FF.

During winter, increasing FF improved starter intake during the entire experimental period, supporting greater intakes of DM, ME, and CP. Feeding MR $3 \times$ daily increased ADG and BW gain but not skeletal growth compared with $2 \times$ a day, suggesting improved adipose tissues or muscle growth, or both. Consistently, in veal calves, increasing $\mathrm{FF}$ from $2 \times$ to $4 \times$ a day improved energy retention as fat and protein (van den Borne et al., 2006). In contrast, during summer, increasing MR FF did not affect starter intake before weaning but supported greater starter intake after weaning, leading to greater postweaning intakes of DM and ME. However, such greater energy consumption after weaning did not support improved growth. These data may reflect the inhibitory effect of heat stress on preweaning intake and growth of neonatal calves.

Abomasal emptying is a critical factor that regulates energy and nutrient utilization in preweaning calves. For instance, with a fixed FF, increasing MR allowance increases meal size and delays abomasal emptying
(MacPherson et al., 2016). This could result in increased abomasal fermentation of carbohydrates (Burgstaller et al., 2017) and increased amino acid oxidation, because temporal plasma amino acid concentrations after feeding exceed the requirement for protein retention (van den Borne et al., 2006, 2007). These suggest reduced energy and nutrients utilizations. In contrast, accelerated abomasal emptying by increasing $\mathrm{FF}$ has been reported to lower heat production, improve energy and protein retention, and reduce amino acid oxidation (van den Borne et al., 2006, 2007). With faster abomasal emptying in this current study, we expected that calves fed MR $3 \times$ daily would have improved energy and nutrient utilization compared with those fed $2 \times$ daily during both seasons. However, increased FF had no effect on ADG/ME in both seasons and improved ADG and BW gain only during winter, not in the summer. These data potentially suggest that increasing $\mathrm{FF}$ alters energy partitioning toward functions rather than growth. The routes of energy use may include heat dissipation, which could partially explain the lower heat load as indicated by lower rectal temperature or respiration rate of calves with increased FF.

We found no effect of FR on apparent nutrient digestibility during the preweaning period in summer and 
winter. Consistently, veal calves fed MR at 1.5 or $2.5 \times$ ME for maintenance had similar nutrient digestibility (van den Borne et al., 2006). In contrast, increasing the FR of a $27: 18 \mathrm{MR}$ from 0.66 to $1.31 \mathrm{~kg}$ of solid per day enhanced digestibility of DM, OM, fat, and CP at 3 wk after birth (Hill et al., 2016b). These data suggest that feeding higher amounts of MR had no negative effect on nutrient digestion during the preweaning period. The reduced digestibility of nutrients provided by starter has been observed in calves offered increased amounts of MR (Weary et al., 2008; Hill et al., 2016b; Dennis et al., 2018, 2019). This was largely attributed to delayed rumen development resulting from lower starter intake (Warner et al., 1956; Tamate et al., 1962; Church, 1988). In the current study, increasing FR from 0.65 to $0.76 \mathrm{~kg}$ of DM per day of a $26: 17 \mathrm{MR}$ did not affect starter intake or digestibility of DM, OM, $\mathrm{CP}$, sugar, and starch provided by calf starter during the postweaning period in both seasons. During sum- mer, calves previously fed high tended to have greater postweaning fat digestibility compared with those fed low. This may suggest that increasing MR allowance improved fat absorption provided by calf starter after weaning during summer but not winter. Interestingly, digestibility of aNDFom tended to be higher with increased FR during the winter postweaning, potentially indicating altered rumen function. However, FR did not affect starter intake during winter, suggesting similar rumen development. Therefore, the mechanisms of the altered fiber digestion by increased MR allowance are unclear. The influence of FF on apparent nutrient digestibility is seldom reported. Veal calves fed $4 \times$ a day had similar nutrient digestibility to those fed $2 \times$ a day (van den Borne et al., 2006). Similarly, FF did not influence nutrient digestibility provided by MR and starter in both seasons, except for fat during winter. Increasing $\mathrm{FF}$ increased fat digestibility before weaning but reduced fat digestibility during the postweaning pe-
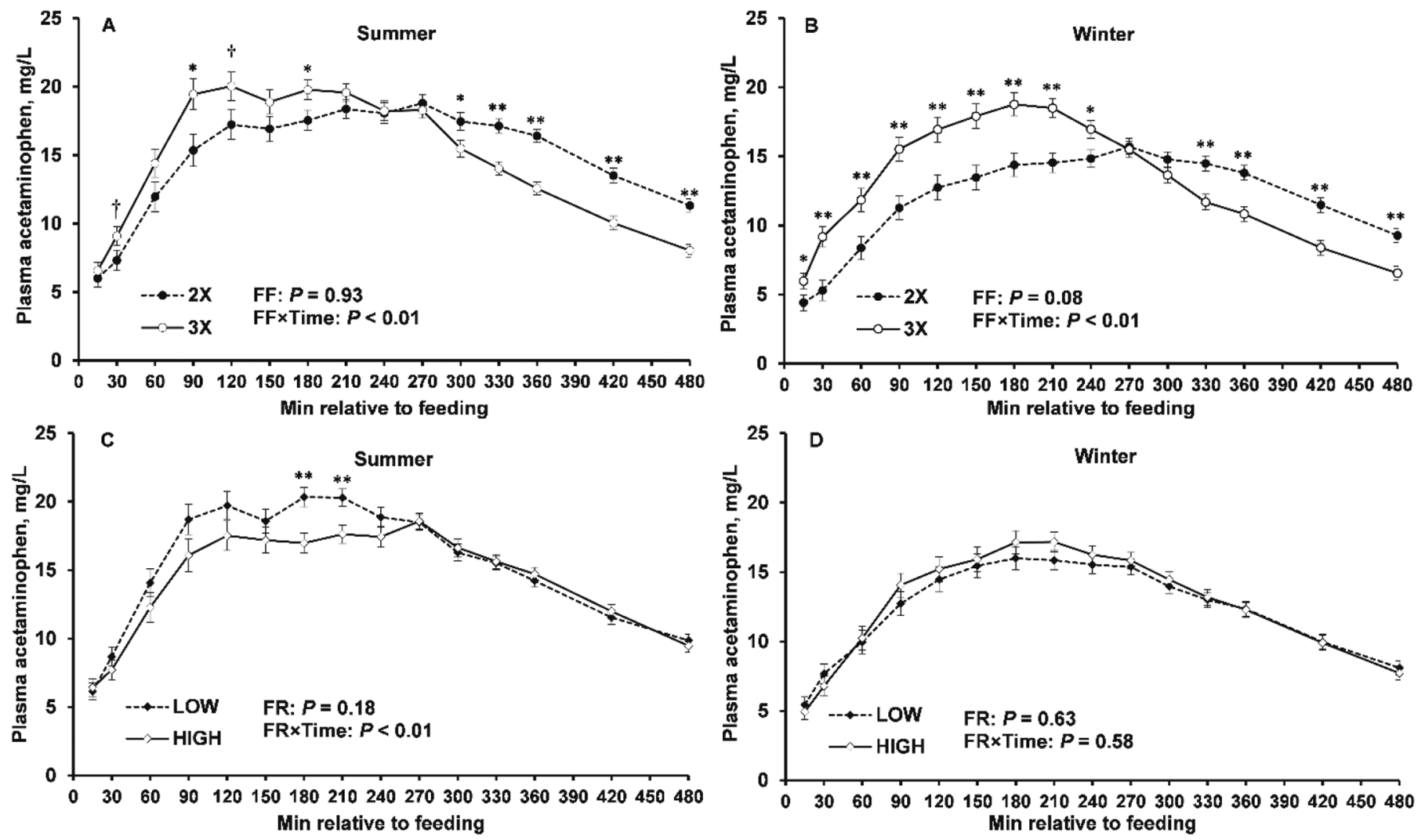

Figure 7. Milk replacer feeding rate [FR, $0.65 \mathrm{~kg}$ of DM/d of a milk replacer containing $26 \% \mathrm{CP}$ and $17 \%$ fat (low, $\mathrm{n}=20 / \mathrm{season})$ vs. 0.76 $\mathrm{kg}$ of $\mathrm{DM} / \mathrm{d}$ of a milk replacer containing $26 \% \mathrm{CP}$ and $17 \%$ fat (high, $\mathrm{n}=20 /$ season)] and frequency [FF, twice $(2 \times, \mathrm{n}=20 /$ season) vs. 3 times per day $(3 \times, \mathrm{n}=20$ /season)] on plasma acetaminophen concentration relative to morning milk replacer feeding $(0700 \mathrm{~h})$ on $20.2 \pm 1.3 \mathrm{~d}$ of age during summer and $20.2 \pm 1.2 \mathrm{~d}$ of age during winter. Errors bars represent SEM. During summer, effect of FR $(P=0.18)$, FF $(P=0.93)$, FR by minute interaction $(P<0.01)$, FF by minute interaction $(P<0.01)$, and FR by FF by minute interaction $(P=0.69)$. During winter, effect of FR $(P=0.63), \mathrm{FF}(P=0.08)$, FR by minute interaction $(P=0.58)$, FF by minute interaction $(P<0.01)$, and FR by FF by minute interaction $(P=0.36) .{ }^{* *} P \leq 0.01,{ }^{*} P \leq 0.05, \dagger P \leq 0.10$. 
riod only for calves fed high during winter. The reasons for the altered fat digestibility are unknown, and their effects on calf growth are also not clear.

In summary, increasing the FR of a 26:17 MR from 0.65 to $0.76 \mathrm{~kg}$ of $\mathrm{DM}$ per day improved nutrient intakes, supporting greater growth of dairy calves in both summer and winter. During the summer but not the winter, increased MR allowance delayed abomasal emptying, potentially due to heat stress. Without regard to season, feeding MR more frequently accelerated the abomasal emptying rate. During the winter, calves fed MR $3 \times$ daily had greater starter intake and ADG compared with those fed $2 \times$ a day. However, similar improvements in growth were not observed in summer. In this experiment, the altered growth performance due to FR or FF could not be explained by different abomasal emptying rates. One limitation of the current experiment is the smaller difference in MR FR. This is mainly because our preliminary study suggests that feeding more than $0.77 \mathrm{~kg}$ per day of a 26:17 MR twice daily increases the incidence of abomasal bloating and mortality (Orellana Rivas et al., 2020). Future research may focus on comparing the effects of individual hutches with limited MR FR and FF versus group housing equipped with an automatic calf feeder that provides increased MR allowance with greater FF on calf growth during summer.

Research to explore feasible nutritional and management approaches to improve calf performance under heat stress conditions is highly needed. Although thermal environment affects animal performance, heat stress is not the only stressor imposed on dairy calves in the summer, and the different treatment responses between summer and winter cannot be attributed only to postnatal heat stress. Indeed, Monteiro et al. (2016) and Laporta et al. (2017) reported that prenatal heat stress during late gestation impairs calves' growth and immunity during their postnatal life. Osborne et al. (2007) also reported that longer day length increases starter intake and ADG of preweaning dairy calves, compared with shorter day length. The increased fly density and wetter bedding due to increased rainfall are additional stressors that affect calf performance during summer. Furthermore, the different types and loads of bacteria present in the rearing environments may affect the etiology and incidences of diseases and growth responses of calves between seasons. Thus, it is important to recognize that these stressors, which cannot be controlled by researchers, in addition to postnatal thermal environments, could also influence dairy calves' growth and their responses to changes in nutrition and management in different seasons.

\section{CONCLUSIONS}

In this experiment, we showed that modestly increasing MR FR improved calf growth in both summer and winter, and observed that summer environments, especially heat stress, delayed abomasal emptying when MR FR is increased. Additionally, against our hypothesis, increasing MR FF from $2 \times$ to $3 \times$ daily failed to improve calf growth during summer. This information will improve the MR feeding program for calves raised in tropical and subtropical climates.

\section{ACKNOWLEDGMENTS}

The authors are grateful for the support provided by the Georgia Agricultural Commodity Commission for Beef (Atlanta, GA); Milk Checkoff, funded by Southeast Milk Inc. (Belleview, FL); and the National Institute of Food and Agriculture (Washington, DC) Hatch project (GEO00916). We also extend appreciation to the staff of the Dairy Research Center of the University of Georgia (Tifton, GA) for animal care and data collection, and to Hannah Goodnight, Morgan Garrick, and Melissa Tawzer at the Department of Animal and Dairy Science of the University of Georgia for their technical support. The authors have not stated any conflicts of interest.

\section{REFERENCES}

AOAC International. 2002. Official Methods of Analysis. 16th ed. AOAC International.

AOAC International. 2005. Official Methods of Analysis. 18th ed. AOAC International.

Bartlett, K. S., F. K. McKeith, M. J. VandeHaar, G. E. Dahl, and J. K. Drackley. 2006. Growth and body composition of dairy calves fed milk replacers containing different amounts of protein at two feeding rates. J. Anim. Sci. 84:1454-1467. https://doi.org/10 $.2527 / 2006.8461454 x$.

Blair, S. J. 2015. Effects of milk replacer and multivitamin-mineral supplementation on performance of heat stressed dairy calves. MS thesis. School of Animal Science, Louisiana State University, Baton Rouge, LA.

Broucek, J., P. Kisac, and M. Uhrincat. 2009. Effect of hot temperatures on the hematological parameters, health and performance of calves. Int. J. Biometeorol. 53:201-208. https://doi.org/10.1007/ s00484-008-0204-1.

Brown, E. G., M. J. VandeHaar, K. M. Daniels, J. S. Liesman, L. T. Chapin, D. H. Keisler, and M. S. W. Nielsen. 2005. Effect of increasing energy and protein intake on body growth and carcass composition of heifer calves. J. Dairy Sci. 88:585-594. https://doi .org/10.3168/jds.S0022-0302(05)72722-3.

Burgstaller, J., T. Wittek, and G. W. Smith. 2017. Invited review: Abomasal emptying in calves and its potential influence on gastrointestinal disease. J. Dairy Sci. 100:17-35. https://doi.org/10 .3168/jds.2016-10949.

Chapman, C. E., P. S. Erickson, J. D. Quigley, T. M. Hill, H. G. Bateman II, F. X. Suarez-Mena, and R. L. Schlotterbeck. 2016. Effect of milk replacer program on calf performance and digestion 
of nutrients with age of the dairy calf. J. Dairy Sci. 99:2740-2747. https://doi.org/10.3168/jds.2015-10372.

Chavez, T. M. 2011. Adjusting milk replacer intake during heat stress and non-heat stress as a means of improving dairy calf performance. MS thesis. Texas A\&M University, College Station, TX.

Church, D. C. 1988. The Ruminant Animal: Digestive Physiology and Nutrition. Waveland Press Inc.

Collier, R. J., L. H. Baumgard, R. B. Zimbelman, and Y. Xiao. 2019 Heat stress: Physiology of acclimation and adaptation. Anim. Front. 9:12-19. https://doi.org/10.1093/af/vfy031.

Constable, P. D., W. Grünberg, and L. Carstensen. 2009. Comparative effects of two oral rehydration solutions on milk clotting, abomasal luminal $\mathrm{pH}$, and abomasal emptying rate in sucking calves. J. Dairy Sci. 92:296-312. https://doi.org/10.3168/jds.2008-1462.

Dennis, T. S., F. X. Suarez-Mena, T. M. Hill, J. D. Quigley, R. L. Schlotterbeck, and L. Hulbert. 2018. Effect of milk replacer feeding rate, age at weaning, and method of reducing milk replacer to weaning on digestion, performance, rumination, and activity in dairy calves to 4 months of age. J. Dairy Sci. 101:268-278. https:/ /doi.org/10.3168/jds.2017-13692.

Dennis, T. S., F. X. Suarez-Mena, W. Hu, T. M. Hill, J. D. Quigley, and R. L. Schlotterbeck. 2019. Effects of milk replacer feeding rate and long-term antibiotic inclusion in milk replacer on performance and nutrient digestibility of Holstein dairy calves up to 4 months of age. J. Dairy Sci. 102:2094-2102. https://doi.org/10.3168/jds .2018-15652.

Diaz, M. C., M. E. Van Amburgh, J. M. Smith, J. M. Kelsey, and E. L. Hutten. 2001. Composition of growth of Holstein calves fed milk replacer from birth to 105-kilogram body weight. J. Dairy Sci. 84:830-842. https://doi.org/10.3168/jds.S0022-0302(01)74541-9.

DuBois, M., K. A. Gilles, J. K. Hamilton, P. A. Rebers, and F. Smith. 1956. Colorimetric method for determination of sugars and related substances. Anal. Chem. 28:350-356. https://doi.org/10.1021/ ac60111a017.

Fenton, T., and M. Fenton. 1979. An improved procedure for the determination of chromic oxide in feed and feces. Can. J. Anim. Sci. 59:631-634. https://doi.org/10.4141/cjas79-081.

Gebremedhin, K. G., C. O. Cramer, and W. P. Porter. 1981. Predictions and measurement of heat production and food and water requirements of Holstein calves in different environments. Trans. ASAE 24:0715-0720. https://doi.org/10.13031/2013.34326.

Grice, K. D., K. M. Glosson, and J. K. Drackley. 2020. Effects of feeding frequency and protein source in milk replacer for Holstein calves. J. Dairy Sci. 103:10048-10059. https://doi.org/10.3168/jds .2020-19041.

Hall, M. B., J. Arbaugh, K. Binkerd, A. Carlson, T. Doan, T. Grant, C. Heuer, H. D. Inerowicz, B. Jean-Louis, R. Johnson, J. Jordan, D. Kondratko, E. Maciel, K. McCallum, D. Meyer, C. A. Odijk, A. Parganlija-Ramic, T. Potts, L. Ruiz, S. Snodgrass, D. Taysom, S. Trupia, B. Steinlicht, and D. Welch. 2015. Dietary starch in animal feeds and pet food by an enzymatic-colorimetric method: Collaborative study. J. AOAC Int. 98:397-409. https://doi.org/10 $.5740 /$ jaoacint.15-012.

Hildebrandt, T., E. Scheuch, W. Weitschies, M. Grimm, F. Schneider, L. Bachmann, and I. Vervuert. 2017. Measurement of abomasal conditions ( $\mathrm{pH}$, pressure and temperature) in healthy and diarrheic dairy calves using a wireless ambulatory capsule. Livest. Sci. 203:41-47. https://doi.org/10.1016/j.livsci.2017.06.011.

Hill, T. M., H. G. Bateman II, J. M. Aldrich, and R. L. Schlotterbeck. 2009. Effects of fat concentration of a high-protein milk replacer on calf performance. J. Dairy Sci. 92:5147-5153. https://doi.org/ 10.3168/jds.2009-2245.

Hill, T. M., H. G. Bateman II, F. X. Suarez-Mena, T. S. Dennis, and R. L. Schlotterbeck. 2016a. Short communication: Changes in body temperature of calves up to 2 months of age as affected by time of day, age, and ambient temperature. J. Dairy Sci. 99:88678870. https://doi.org/10.3168/jds.2016-10994.

Hill, T. M., J. D. Quigley, F. X. Suarez-Mena, H. G. Bateman II, and R. L. Schlotterbeck. 2016b. Effect of milk replacer feeding rate and functional fatty acids on dairy calf performance and digestion of nutrients. J. Dairy Sci. 99:6352-6361. https://doi.org/10.3168/ jds.2015-10812.

Kirchner, D., L. Schwedhelm, J. Wenge, I. Steinhöfel, C. Heinrich, M. Coenen, and L. Bachmann. 2015. Ultrasonographic imaging of abomasal milk clotting and abomasal diameter in healthy and diarrheic calves. Anim. Sci. J. 86:929-936. https://doi.org/10.1111/ asj.12382.

Kmicikewycz, A. D., D. N. L. da Silva, J. G. Linn, and N. B. Litherland. 2013. Effects of milk replacer program fed 2 or 4 times daily on nutrient intake and calf growth. J. Dairy Sci. 96:1125-1134. https://doi.org/10.3168/jds.2012-5738.

Laporta, J., T. F. Fabris, A. L. Skibiel, J. L. Powell, M. J. Hayen, K. Horvath, E. K. Miller-Cushon, and G. E. Dahl. 2017. In utero exposure to heat stress during late gestation has prolonged effects on the activity patterns and growth of dairy calves. J. Dairy Sci. 100:2976-2984. https://doi.org/10.3168/jds.2016-11993.

MacPherson, J., S. J. Meale, K. Macmillan, J. Haisan, C. J. Bench, M. Oba, and M. A. Steele. 2019. Effects of feeding frequency of an elevated plane of milk replacer and calf age on behavior, and glucose and insulin kinetics in male Holstein calves. Animal 13:1385-1393. https://doi.org/10.1017/S175173111800294X.

MacPherson, J. A. R., H. Berends, L. N. Leal, J. P. Cant, J. MartinTereso, and M. A. Steele. 2016. Effect of plane of milk replacer intake and age on glucose and insulin kinetics and abomasal emptying in female Holstein Friesian dairy calves fed twice daily. J. Dairy Sci. 99:8007-8017. https://doi.org/10.3168/jds.2015-10826.

Marshall, T. S., P. D. Constable, S. S. Crochik, and T. Wittek. 2005 Determination of abomasal emptying rate in suckling calves by use of nuclear scintigraphy and acetaminophen absorption. Am. J. Vet. Res. 66:364-374. https://doi.org/10.2460/ajvr.2005.66.364.

McDowell, R. E., E. G. Moody, P. J. Van Soest, R. P. Lehmann, and G. L. Ford. 1969. Effect of heat stress on energy and water utilization of lactating cows. J. Dairy Sci. 52:188-194. https://doi.org/10 .3168/jds.S0022-0302(69)86528-8.

Miller-Cushon, E. K., R. Bergeron, K. E. Leslie, and T. J. DeVries. 2013. Effect of milk feeding level on development of feeding behavior in dairy calves. J. Dairy Sci. 96:551-564. https://doi.org/10 $.3168 /$ jds.2012-5937.

Monteiro, A. P. A., J.-R. Guo, X.-S. Weng, B. M. Ahmed, M. J. Hayen, G. E. Dahl, J. K. Bernard, and S. Tao. 2016. Effect of maternal heat stress during the dry period on growth and metabolism of calves. J. Dairy Sci. 99:3896-3907. https://doi.org/10.3168/jds .2015-10699.

Nonaka, I., N. Takusari, K. Tajima, T. Suzuki, K. Higuchi, and M. Kurihara. 2008. Effects of high environmental temperatures on physiological and nutritional status of prepubertal Holstein heifers. Livest. Sci. 113:14-23. https://doi.org/10.1016/j.livsci.2007.02 .010 .

NRC (National Research Council). 2001. Nutrient Requirements of Dairy Cattle. 7th rev. ed. National Academies Press

Orellana Rivas, R. M., G. H. Komori, V. V. Beihling, T. N. Marins, J. K. Bernard, and S. Tao. 2020. Effects of milk replacer feeding levels on performance and metabolism of preweaned dairy calves during summer. J. Dairy Sci. 103:313-324. https://doi.org/10.3168/ jds.2019-17360.

Osborne, V. R., N. E. Odongo, A. M. Edwards, and B. W. McBride. 2007. Effects of photoperiod and glucose-supplemented drinking water on the performance of dairy calves. J. Dairy Sci. 90:51995207. https://doi.org/10.3168/jds.2007-0402.

Piccione, G., G. Caola, and R. Refinetti. 2003. Circadian rhythms of body temperature and liver function in fed and food-deprived goats. Comp. Biochem. Physiol. A Mol. Integr. Physiol. 134:563572. https://doi.org/10.1016/S1095-6433(02)00362-8.

Quigley, J. D., T. M. Hill, T. S. Dennis, F. X. Suarez-Mena, and R. L. Schlotterbeck. 2018. Effects of feeding milk replacer at 2 rates with pelleted, low-starch or texturized, high-starch starters on calf performance and digestion. J. Dairy Sci. 101:5937-5948. https:// doi.org/10.3168/jds.2017-13851.

Schingoethe, D. J., D. P. Casper, J. K. Drackley, and F. C. Ludens. 1986. Increased solids intake and feeding frequency for calves in 
hutches during cold weather. J. Dairy Sci. 69:1063-1069. https:// doi.org/10.3168/jds.S0022-0302(86)80502-1.

School of Veterinary Medicine, University of Wisconsin-Madison. 2011. Calf health scoring chart and calf health scoring criteria. Accessed May 2, 2016. https://fyi.extension.wisc.edu/heifermgmt/ files/2015/02/calf_health_scoring_chart.pdf.

Sockett, D. C., C. E. Sorenson, N. K. Betzold, J. T. Meronek, and T. J. Earleywine. 2011. Impact of three times versus twice a day milk replacer feeding on calf performance, likelihood to reach lactation and future milk production in a commercial dairy herd. J. Dairy Sci. 94(Suppl. 2):264. (Abstr.)

Stanley, C. C., C. C. Williams, B. F. Jenny, J. M. Fernandez, H. G. Bateman II, W. A. Nipper, J. C. Lovejoy, D. T. Gantt, and G. E. Goodier. 2002. Effects of feeding milk replacer once versus twice daily on glucose metabolism in Holstein and Jersey calves. J. Dairy Sci. 85:2335-2343. https://doi.org/10.3168/jds.S0022 -0302(02)74313-0.

Stull, C. L., L. L. McV. Messam, C. A. Collar, N. G. Peterson, A. R. Castillo, B. A. Reed, K. L. Andersen, and W. R. VerBoort. 2008. Precipitation and temperature effects on mortality and lactation parameters of dairy cattle in California. J. Dairy Sci. 91:45794591. https://doi.org/10.3168/jds.2008-1215.

Tamate, H., A. D. McGilliard, N. L. Jacobson, and R. Getty. 1962. Effect of various dietaries on the anatomical development of the stomach in the calf. J. Dairy Sci. 45:408-420. https://doi.org/10 .3168/jds.S0022-0302(62)89406-5.

USDA. 2016. Dairy 2014: Dairy Cattle Management Practices in the United States, 2014. USDA-NAHMS (National Animal Health Monitoring System).

van den Borne, J. J. G. C., G. E. Lobley, M. W. A. Verstegen, J.M. Muijlaert, S. J. J. Alferink, and W. J. J. Gerrits. 2007. Body fat deposition does not originate from carbohydrates in milk-fed calves. J. Nutr. 137:2234-2241. https://doi.org/10.1093/jn/137.10 .2234 .

van den Borne, J. J. G. C., M. W. A. Verstegen, S. J. J. Alferink, R. M. M. Giebels, and W. J. J. Gerrits. 2006. Effects of feeding frequency and feeding level on nutrient utilization in heavy preruminant calves. J. Dairy Sci. 89:3578-3586. https://doi.org/10.3168/ jds.S0022-0302(06)72397-9.

Warner, R., W. Flatt, and J. Loosli. 1956. Ruminant nutrition, dietary factors influencing development of ruminant stomach. J. Agric. Food Chem. 4:788-792. https://doi.org/10.1021/jf60067a003.

Weary, D. M., J. Jasper, and M. J. Hötzel. 2008. Understanding weaning distress. Appl. Anim. Behav. Sci. 110:24-41. https://doi.org/ 10.1016/j.applanim.2007.03.025. 